\title{
Dual function of membrane-bound heat shock protein 70 (Hsp70), Bag-4, and Hsp40: protection against radiation-induced effects and target structure for natural killer cells
}

\author{
M Gehrmann', J Marienhagen², H Eichholtz-Wirth ${ }^{3}$, E Fritz ${ }^{3}$, \\ J Ellwart ${ }^{4}$, M Jäättelä ${ }^{5}$, T Zilch ${ }^{1}$ and G Multhoff*,1 \\ 1 Department of Hematology and Internistic Oncology, University Hospital \\ Regensburg, Franz-Josef-Strauss Allee 11, 93053 Regensburg, Germany \\ 2 Department of Nuclear Medicine, University Hospital Regensburg, \\ Franz-Josef-Strauss Allee 11, 93053 Regensburg, Germany \\ ${ }^{3}$ GSF - National Research Center for Environment and Health, Institute of \\ Molecular Radiobiology, Ingolstädter Landstr. 1, 85758 Neuherberg, Germany \\ 4 GSF - National Research Center for Environment and Health, Institute of \\ Molecular Immunology, Marchioninistr. 25, 81377 Munich, Germany \\ 5 Institute of Cancer Biology, Apoptosis Laboratory, Strandboulevarden 49, \\ 2100 Copenhagen, Denmark \\ * Corresponding author: G Multhoff, Molecular Oncology, Department of \\ Hematology and Internistic Oncology, University Hospital Regensburg, \\ Franz-Josef-Strauss Allee 11, 93053 Regensburg, Germany. \\ Tel: + 49941944 5575; Fax: + 49941944 5572; \\ E-mail: gabriele.multhoff@klinik.uni-regensburg.de
}

Received 09.7.04; accepted 17.8.04

Edited by G Melino

\section{Abstract}

CX $+/$ CX - and Colo $+/$ Colo - tumor sublines with stable heat shock protein 70 (Hsp70) high and low membrane expression were generated by fluorescence activated cell sorting of the parental human colon (CX2) and pancreas (Colo357) carcinoma cell lines, using an Hsp70-specific antibody. Two-parameter flow cytometry revealed that Hsp70 colocalizes with Bag-4, also termed silencer of death domain, not only in the cytosol but also on the plasma membrane. After nonlethal $\gamma$-irradiation, the percentage of membranepositive cells and the protein density of Hsp70 and Bag-4 were found to be strongly upregulated in carcinoma sublines with initially low expression levels ( $\mathrm{CX}_{-}$, Colo-). Membrane expression of Hsp70 was also elevated in Bag-4 overexpressing HeLa cervix carcinoma cells when compared to neo-transfected cells. In response to $\gamma$-irradiation, neotransfected HeLa cells behaved like Hsp70/Bag-4 lowexpressing $\mathrm{CX}_{-}$and Colo-, and Bag-4-transfected HeLa cells like Hsp70/Bag-4 high-expressing carcinoma sublines $\mathrm{CX}+$ and Colo + . Immunoprecipitation studies further confirmed colocalization of Hsp70 and Bag-4 but also point to an association of $\mathrm{Hsp70}$ and Hsp4O on the plasma membrane of CX + and Colo + cells; on CX - and Colotumor sublines, Hsp40 was detectable in the absence of Hsp70 and Bag-4. Other co-chaperones including Hsp60 and Hsp90 were neither found on the cell surface of $\mathbf{C X}+/ \mathrm{CX}_{-}$, Colo +/Colo- nor on HeLa neo-/HeLa Bag-4-transfected tumor cells. Functionally, Hsp70/Bag-4 and Hsp70/Hsp40 membrane-positive tumor cells appeared to be better protected against radiation-induced effects, including G2/M arrest and growth inhibition, on the one hand. On the other hand, membrane-bound Hsp70, but neither Bag-4 nor Hsp40, served as a recognition site for the cytolytic attack mediated by natural killer cells.

Cell Death and Differentiation (2005) 12, 38-51.

doi:10.1038/sj.cdd. 4401510

Keywords: G2/M arrest; $\gamma$-irradiation; Hsp70/Bag-4/Hsp40 membrane expression; NK cells

Abbreviations: ATP, adenosine 5'-triphosphate; Bag, Bcl-2associated athanogene; DR3, death receptor 3; FITC, fluorescein isothiocyanate; HGF, hepatocyte growth factor; Hip, heat shock protein interacting protein; HSP, heat shock protein family; Hsp70, heat shock protein 70 family member; NK cell, natural killer cell; PDGF, platelet-derived growth factor; Raf, serine/ threonine protein kinase; SODD, silencer of death domain; TNF, tumor necrosis factor; TNFR1, TNF receptor 1

\section{Introduction}

Heat shock proteins (HSPs) are highly conserved molecules known to mediate protection against lethal damage after a variety of different stress stimuli in procaryotic and eucaryotic cells. Also under physiological conditions, they support folding of non-native and misfolded proteins, and prevent aggregation during proliferation and cellular differentiation. ${ }^{1}$ One of the best-characterized chaperones belong to the HSP70 family. Similar to other stress proteins, HSP70s are most efficient when they operate in concert with co-chaperones including HSP40s, HSP60s, and HSP90s. Together with J-domain chaperones, they support protein folding and assist translocation processes across membranes. ${ }^{2}$ Adenosine $5^{\prime}$-triphosphate (ATP) hydrolysis, stabilizing HSP70 substrate complexes, is much faster in collaboration with the HSPinteracting protein Hip. ${ }^{3}$ Apoptosis initiated either by exogenous factors (i.e. tumor necrosis factor $\alpha$, TNF $\alpha$ ) or spontaneous crosslinking of the death domain receptors TNF receptor 1 (TNFR1), death receptor 3 (DR3) is inhibited in the presence of high amounts of $\mathrm{Hsc70}$ and $\mathrm{Hsp} 70,{ }^{4}$ in combination with members of the antiapoptotic Bcl-2-associated athanogene (BAG) family. They share a highly conserved 45aa BAG domain consisting of three-helix bundles of variable length and a diverse $\mathrm{N}$-terminal sequence. ${ }^{5}$ Four BAG proteins (Bag-1, $-3,-4$, and -6 ) have been reported to compete with Hip for binding to the ATPase domain of HSP70s, and thus promote chaperone activity. ${ }^{6,7}$ It 
was also assumed that BAG proteins operate as cellular adaptors targeting HSP70/BAG complexes to the cytosolic domain of the $55 \mathrm{kDa}$ TNFR1, and thereby inhibit receptor aggregation and activation of the death domains via TRADD, FADD, TRAF and RIP. ${ }^{8}$ On the one hand, overexpression of Bag-4, also termed as the silencer of death domain (SODD), has been found to suppress TNF-induced apoptosis ${ }^{9}$ and, on the other hand, in mice, increased HSP70 levels are known to confer protection against TNF-mediated lethal shock. ${ }^{10} \mathrm{BAG}$ proteins were also discussed as important cofactors, affecting the ATPase cycle of HSP70s. ${ }^{9}$ The availability of hydrolyzable ATP regulates BAG binding. Apart from TNFR1, BAG proteins interact with $\mathrm{Bcl}-2,{ }^{11}$ serine/threonine protein kinase (Raf kinase), ${ }^{12}$ androgen-,${ }^{13}$ hepatocyte growth factor (HGF)-, and platelet-derived growth factor (PDGF) receptors. ${ }^{14}$ Following stress, when cytosolic HSP70 levels are upregulated, the $\mathrm{BAG} /$ receptor complexes might be replaced by BAG/HSP70 complexes.

In the present study, we compared the interaction of the stress-inducible $\mathrm{Hsp} 70$ and Bag-4 under physiological conditions and after $\gamma$-irradiation-induced stress in carcinoma cells with initially different Hsp70 membrane expression pattern. Although the molecular basis for the interaction between the ATPase domain of Hsp70 and the short BAG domain of Bag-4 has been studied extensively, ${ }^{13,15}$ knowledge on stressinduced modulations in the plasma membrane is limited. Previously, we and others demonstrated a tumor-selective Hsp70 plasma membrane localization by cell surface iodination followed by SDS-PAGE and by flow cytometry of viable tumor cells, using an Hsp70-specific monoclonal antibody. ${ }^{16,17}$ These findings are in line with recently published data, ${ }^{18}$ showing an abundance of molecular chaperones, including Hsp70, in the plasma membrane of tumor cells by global proteome analysis of surface-bound proteins. In this context, we were also interested to identify other cochaperones including Hsp40, Hsp60, and Hsp90 that might be associated with Hsp70/Bag-4 on the cell membrane.

We have also shown that the amount of membrane-bound Hsp70 on tumor cells could be modulated by membraneinteractive reagents ${ }^{19}$ and cytostatic drugs. ${ }^{20}$ Also, radiation has been found to affect cytosolic Hsp70 levels in tumor cells. ${ }^{21-23}$ Since $\gamma$-irradiation is frequently used in cancer therapy, ${ }^{24,25}$ it is important to understand the molecular nature of radiation-induced effects on resistance of tumor cells to apoptosis. $^{26,27}$ Therefore, we investigated radiation-induced effects in three independent carcinoma cell systems that differ with respect to their capacity to express Hsp70 on their cell surface. Concomitantly, the effects of Bag-4 as an Hsp70interacting, antiapoptotic molecule were investigated. We found that $\mathrm{Hsp} 70$ was associated with Bag-4 and with $\mathrm{Hsp} 40$ not only in the cytosol but also on the plasma membrane. Following nonlethal $\gamma$-irradiation, the chaperone complex was found to be upregulated in carcinoma cells with initially low Hsp70 expression levels. On the one hand, functionally, an Hsp70/Bag-4/Hsp40-positive phenotype conferred protection against irradiation-induced effects including G2/M arrest and growth inhibition and, on the other hand, Hsp70, but not associated proteins, served as a recognition structure for the cytolytic attack mediated by natural killer (NK) cells.

\section{Results}

\section{$\gamma$-Irradiation induces an increase in membrane- bound Hsp70 and Bag-4 in initially low-expressing carcinoma sublines}

By cell sorting of the parental CX2 colon and Colo357 pancreas carcinoma cell lines, using the Hsp70-specific monoclonal antibody cmHsp70.1 (Table 1), stably Hsp70 high- ( $\mathrm{CX}+$ : $>80 \%$; Colo + : $>75 \%)$ and low-expressing (CX-: $<30 \%$; Colo-: $<35 \%$ ) tumor sublines were generated. To determine the nonlethal irradiation dose, exponentially growing carcinoma sublines with initially different Hsp70 membrane expression pattern were irradiated, either fractionated $(2 \times 2$ and $5 \times 2 \mathrm{~Gy})$, or with a single dose of $1 \times 10$ or $1 \times 20 \mathrm{~Gy}$, respectively. Up to a total irradiation dose of $1 \times 10 \mathrm{~Gy}$, and a recovery period of $24 \mathrm{~h}$ at $37^{\circ} \mathrm{C}$, cell viability of colon and pancreas carcinoma sublines remained unaffected (Table $2 \mathrm{a}$ ). $\gamma$-Irradiation at $1 \times 20$ Gy resulted in a significant loss of cell viability in Hsp70 low-expressing CXand Colo- tumor cells (Table 2a). Viability of HeLa cervix carcinoma cells transfected with neo vector was only marginally reduced after irradiation of $1 \times 20$ Gy (Table $2 a)$. Annexin$\mathrm{V}$-fluorescein isothiocyanate (FITC) staining confirmed the data obtained by Trypan blue exclusion assays. None of the tumor sublines showed significant increase in Annexin-V-

Table 1 List of antibodies used for fluorescence-activated CS, WB analysis FC, IP, and ABS

\begin{tabular}{|c|c|c|c|}
\hline Antibody & Specificity & Recognition site & Assay \\
\hline $\begin{array}{l}\text { Poly/monoclonal, isotypic control } \\
\text { Monoclonal mouse IgG1, cmHsp70.1 } \\
\text { Polyclonal rabbit Ig, H-300 } \\
\text { Polyclonal rabbit Ig, IMG-152 } \\
\text { Polyclonal goat Ig, N-19 } \\
\text { Polyclonal rabbit Ig, FL-274 } \\
\text { Polyclonal goat Ig, C-16 } \\
\text { Monoclonal mouse IgG2a, SPA-450 (2E1) } \\
\text { Polyclonal rabbit Ig, SPA-400 } \\
\text { Monoclonal mouse IgG1, SPA-806 } \\
\text { Monoclonal mouse IgG1, SPA-830 } \\
\text { Monoclonal mouselgG1, Ab-1 }\end{array}$ & $\begin{array}{l}\text { Isotype } \\
\text { Hsp70 } \\
\text { Bag-4 } \\
\text { Bag-4 } \\
\text { Bag-4 } \\
\text { Bag-1, p50 } \\
\text { Bag-1, p32, p36, p50 } \\
\text { Hsp40 } \\
\text { Hsp40 } \\
\text { Hsp60 } \\
\text { Hsp90 } \\
\text { Tubulin, p60 }\end{array}$ & $\begin{array}{l}\text { Not determined } \\
\text { C-terminus, aa } a_{450-463} \\
\text { C-terminus, aa }{ }_{158-457} \\
\text { C-terminus, aa }{ }_{443-457} \\
\text { N-terminus } \\
\text { Full length, aa }{ }_{1-274} \\
\text { C-terminus } \\
\text { J domain, } \text { aa }_{1-70} \\
\text { Full length, } \text { aa }_{1-340} \\
\text { C-terminus, aa } \text { aa }_{383-447} \\
\text { C-terminus, aa } \\
\text { Not determined }\end{array}$ & $\begin{array}{l}\text { FC } \\
\text { CS, WB, FC, ABS } \\
\text { WB, FC, ABS } \\
\text { WB, FC, ABS } \\
\text { WB, FC, ABS } \\
\text { WB, FC, ABS } \\
\text { WB, FC, ABS } \\
\text { IP, ABS } \\
\text { FC, IP, ABS } \\
\text { FC, IP, ABS } \\
\text { FC, IP, ABS } \\
\text { WB }\end{array}$ \\
\hline
\end{tabular}


Table 2a Viability (\%) of tumor cells following single or fractionated $\gamma$-irradiation as determined by Trypan blue exclusion

\begin{tabular}{|c|c|c|c|c|c|}
\hline Tumor & Control & $2 \times 2$ Gy & $5 \times 2$ Gy & 1 ×10 Gy & 1 × 20 Gy \\
\hline $\begin{array}{l}\mathrm{CX}+ \\
\mathrm{CX}-\end{array}$ & $\begin{array}{l}100 \pm 0.0^{a} \\
100 \pm 0.0\end{array}$ & $\begin{array}{r}100 \pm 0.0 \\
96.6 \pm 0.9\end{array}$ & $\begin{array}{l}97.8 \pm 2.1 \\
96.0 \pm 0.1\end{array}$ & $\begin{array}{l}96.6 \pm 0.0 \\
98.6 \pm 0.0\end{array}$ & $\begin{array}{c}95.0 \pm 2.8 \\
87.5^{\star} \pm 0.02 \\
(P<0.02)\end{array}$ \\
\hline $\begin{array}{l}\text { Colo+ } \\
\text { Colo- }\end{array}$ & $\begin{array}{l}100 \pm 0.1 \\
100 \pm 0.0\end{array}$ & $\begin{array}{l}\text { NT } \\
\text { NT }\end{array}$ & $\begin{array}{l}\text { NT } \\
\text { NT }\end{array}$ & $\begin{array}{l}97.0 \pm 0.7 \\
90.8 \pm 1.2\end{array}$ & $\begin{array}{r}88.9 \pm 0.6 \\
80.5^{\star} \pm 5.3 \\
(P<0.02)\end{array}$ \\
\hline $\begin{array}{l}\text { HeLa Bag-4 } \\
\text { HeLa neo }\end{array}$ & $\begin{array}{l}100 \pm 0.1 \\
100 \pm 0.0\end{array}$ & $\begin{array}{l}\text { NT } \\
\text { NT }\end{array}$ & $\begin{array}{l}\text { NT } \\
\text { NT }\end{array}$ & $\begin{array}{l}97.7 \pm 1.3 \\
98.0 \pm 0.1\end{array}$ & $\begin{array}{l}96.7 \pm 1.9 \\
91.4 \pm 0.6\end{array}$ \\
\hline
\end{tabular}

On day 2 after cell passage, exponentially growing, adherent carcinoma cells were irradiated with different doses as indicated. Following a $24 \mathrm{~h}$ recovery period at $37^{\circ} \mathrm{C}$, cell viability was determined by Trypan blue exclusion assays. Data represent mean values of viable cell counts derived from three independent experiments; NT, not tested; *Values significantly different from control $(P<0.02)$ a $\%$ viable cells

Table 2b Percentage of Annexin-V-FITC positively stained, apoptotic tumor cells following single $\gamma$-irradiation

\begin{tabular}{|c|c|c|c|}
\hline Tumor & Control & $1 \times 10$ Gy & $n$ \\
\hline $\begin{array}{l}\mathrm{CX}+ \\
\mathrm{CX}-\end{array}$ & $\begin{array}{l}11.8 \pm 2.3 \\
17.4 \pm 9.2\end{array}$ & $\begin{array}{l}11.6 \pm 1.3 \\
19.2 \pm 7.0\end{array}$ & $\begin{array}{l}5 \\
5\end{array}$ \\
\hline $\begin{array}{l}\text { Colo+ } \\
\text { Colo- }\end{array}$ & $\begin{array}{l}18.5 \pm 4.4 \\
17.2 \pm 3.7\end{array}$ & $\begin{array}{l}24.8 \pm 7.8 \\
25.0 \pm 2.5\end{array}$ & $\begin{array}{l}6 \\
6\end{array}$ \\
\hline $\begin{array}{l}\text { HeLa Bag-4 } \\
\text { HeLa neo }\end{array}$ & $\begin{array}{l}17.0 \pm 5.6 \\
10.0 \pm 5.1\end{array}$ & $\begin{array}{l}10.0 \pm 5.6 \\
12.9 \pm 8.7\end{array}$ & $\begin{array}{l}4 \\
4\end{array}$ \\
\hline
\end{tabular}

On day 2 after cell passage, exponentially growing, adherent carcinoma cells were irradiated with a single dose of $1 \times 10 \mathrm{~Gy}$. Following a $24 \mathrm{~h}$ recovery period at $37^{\circ} \mathrm{C}$, apoptotic cell death was determined by Annexin-V-FITC staining. The data represent mean values of indicated numbers of experiments \pm S.E.: none of the data is significantly different $(P<0.05)$ as compared to control values

FITC-positive apoptotic cells after treatment with $1 \times 10$ Gy (Table 2b), whereas irradiation at $1 \times 20$ Gy resulted in significant apoptosis (Nylandsted J, Gyrd-Hansen M, Danielewicz A, Fehrenbacher N, Lademann U, Hoyer-Hansen M, Weber E, Multhoff G, Rohde M and Jaattela M (2004) Heat shock protein 70 promotes cell survival by inhibiting lysosomal membrane permeabilization. J. Exp. Med. 200: 425-435). With respect to these findings, all further experiments were performed with the nonlethal $\gamma$-irradiation dose of $1 \times 10 \mathrm{~Gy}$, followed by a recovery period of $24 \mathrm{~h}$ at $37^{\circ} \mathrm{C}$.

Although the carcinoma sublines $\mathrm{CX}+/ \mathrm{CX}-$ and Colo $+/$ Colo- differed significantly in their capacity to express Hsp70 on the cell surface, the cytosolic Hsp70 content was comparable in both tumor subline systems. Even after nonlethal $\gamma$-irradiation, the cytosolic Hsp70 content remained unaltered, as determined by quantitative Western blot analysis related to tubulin (Figure 1a and b, upper part).

It is well known that Bag-4 interacts with the ATPase domain of Hsp70 in the cytosol. ${ }^{13,15}$ Therefore, in addition to Hsp70, the cytosolic amount of Bag-4 was measured in untreated and $\gamma$-irradiated colon $(\mathrm{CX}+/ \mathrm{CX}-$ ) and pancreas (Colo $+/$ Colo-) carcinoma sublines, using the Bag-4-specific antibodies $\mathrm{H}-300$ and IMG-152 (Table 1) and related to tubulin. Epithelial carcinoma were described to have elevated Bag-4 expression levels, ${ }^{28}$ conferring resistance to TNF-induced cell death. Our data are in line with these findings; the relative protein amount of Bag-4 (Figure 1, lower part) was found to be elevated when compared to that of Hsp70 (Figure 1, upper part) in colon and pancreas carcinoma sublines.

Identical to Hsp70, following nonlethal $\gamma$-irradiation at $1 \times 10 \mathrm{~Gy}$, the cytosolic Bag-4 content remained unaltered in all tumor sublines (Figure 1a and b, lower part). Comparable results were observed with respect to Bag-1, using antibodies FL-274 and C-16 (Table 1) directed against full-length, p50, p36, and p32, respectively, in untreated and irradiated (1×10 Gy) CX + and CX - tumor sublines (data not shown).

Although, the cytosolic amount of Hsp70 and Bag-4 remained unaltered after nonlethal $\gamma$-irradiation, the cell surface expression pattern of $\mathrm{Hsp} 70$ was analyzed. As indicated in Figure 2a (upper graph), the percentage of Hsp70 membrane-positive cells remained unaltered and high in $\mathrm{CX}+$ carcinoma cells after $\gamma$-irradiation (82 versus $81 \%$ ). However, a significant increase in the percentage of $\mathrm{Hsp} 70$ membrane-positive cells was determined in $\mathrm{CX}$ - carcinoma cells $(P<0.04)$; the percentage of Hsp70-positive cells rose from 34 to $59 \%$, indicating a translocation of cytosolic Hsp70 to the plasma membrane. Interestingly, Hsp70 membranepositive CX + cells were also found to be strongly positive for Bag-4 (74\%, IMG-152; 78\%, H-300), as measured by two independent Bag-4 antibodies (Table 3). Both antibodies recognize a sequence in the C-terminal domain of Bag-4 (Table 1). In contrast, a Bag-4, antibody whose epitope is localized in the $\mathrm{N}$-terminus $(\mathrm{N}-19)$, and antibodies directed against Bag-1 (FL-274, C-16) were unable to detect plasma membrane-bound BAG molecules on viable tumor cells (Table 3).

Only $42 \%$ of the Hsp70 low-expressing CX-cells exhibited a Bag-4-positive phenotype (Figure 2a, lower graph). Similarly, a significant elevation in Bag-4 expressing cells (42 to $73 \%$ ) was predominantly found in $\mathrm{CX}$ - cells but not in CX + cells (78 to $79 \%$ ). The affinity of the Hsp70- and Bag-4specific antibodies was identical, as indicated by comparable 
mean fluorescence intensity (mfi) values in untreated and treated tumor sublines (Figure 2, right part). After irradiation, a significant increase in the protein density of Hsp70 $(P<0.03)$ and Bag-4 $(P<0.02)$ proteins was detected in $\mathrm{CX}-$ cells
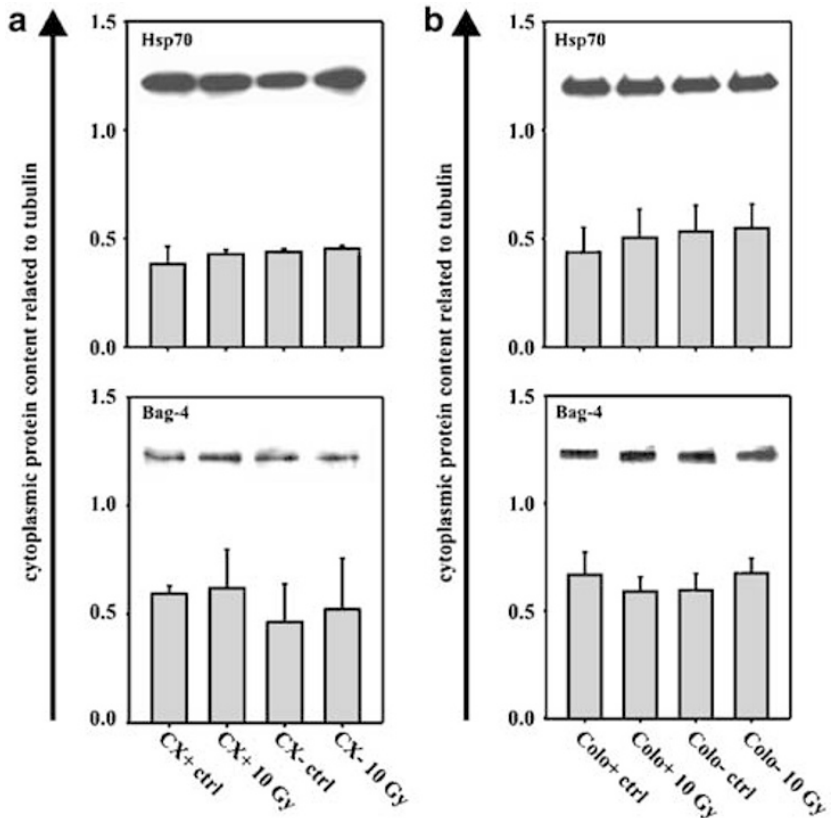

Figure 1 Cytosolic Hsp70 and Bag-4 levels remained unaltered in colon $(\mathrm{CX}+/ \mathrm{CX}-)$ and pancreas (Colo $+/$ Colo-) carcinoma sublines after nonlethal $\gamma$-irradiation. Adherent growing $\mathrm{CX}+/ \mathrm{CX}-$ (a) and Colo $+/ \mathrm{Colo}-$ (b) carcinoma cells were kept either untreated (ctrl) or were irradiated $(1 \times 10 \mathrm{~Gy})$. After a recovery period of $24 \mathrm{~h}$, cell lysates were prepared, and equal protein amounts $(10 \mu \mathrm{g})$ were run on a $10 \%$ SDS-PAGE and transferred to nitrocellulose membranes. Western blots were stained with Hsp70 (cmHsp70.1)- and Bag-4 $(\mathrm{H}-300)$-specific antibodies. Characteristics of the different antibodies are summarized in Table 1. Data show one representative Western blot analysis and mean values as histograms of four independent experiments \pm S.E.; none of the values was statistically different from control, as determined by the Student's t-test
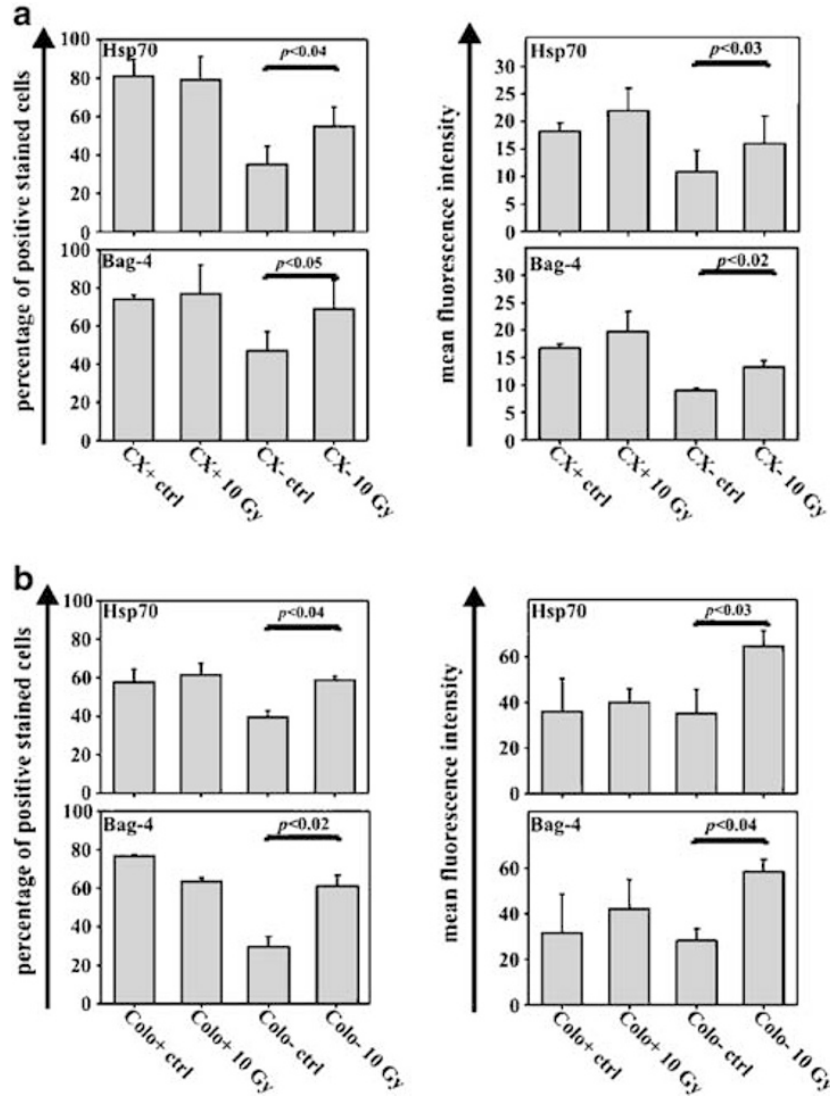

Figure 2 Cell surface expression of Hsp70 and Bag-4 was upregulated on Hsp70 low-expressing colon (CX-) and pancreas (Colo-) carcinoma sublines after nonlethal $\gamma$-irradiation. The percentage of positively stained cells (left part) and the mean flurorescence intensity (right part) of Hsp70 and Bag-4 were determined by flow cytometry on untreated (ctrl) and $\gamma$-irradiated $(1 \times 10 \mathrm{~Gy})$ colon (a: $\mathrm{CX}+/ \mathrm{CX}-$ ) and pancreas (b: Colo $+/$ Colo-) carcinoma cells, using Bag-4-specific antibodies recognizing the C-terminal localized BAG domain (Table 1). Histograms represent mean values of eight (Hsp70) and seven (Bag-4) independent experiments \pm S.E.; significant differences are indicated as $P$-values in each histogram

Table 3 Percentage of positively stained tumor cells using different antibodies directed against Bag-1, Bag-4, Hsp70, Hsp40, Hsp60, and Hsp90

\begin{tabular}{|c|c|c|c|c|c|c|}
\hline $\begin{array}{l}\text { Tumor } \\
\text { Antibody }\end{array}$ & $\mathrm{CX}+$ & $\mathrm{CX}-$ & Colo+ & Colo- & HeLa Bag-4 & HeLa neo \\
\hline $\begin{array}{l}\text { Bag-1 } \\
\text { C-16 }\end{array}$ & $0.5 \pm 0(n=3)$ & $2.3 \pm 1.3(n=3)$ & $1.0 \pm 1.0(n=3)$ & $1.5 \pm 0.5(n=3)$ & NT & NT \\
\hline $\begin{array}{l}\text { Bag-1 } \\
\text { FL-274 }\end{array}$ & $2.9 \pm 0.2(n=3)$ & $2.2 \pm 0.2(n=3)$ & $2.0 \pm 2.3(n=3)$ & $1.8 \pm 0.5(n=3)$ & NT & NT \\
\hline $\begin{array}{l}\text { Bag-4 } \\
\text { N-19 }\end{array}$ & $2.4 \pm 1.6(n=3)$ & $0 \pm 0(n=3)$ & $0 \pm 0(n=3)$ & $1.0 \pm 0.5(n=3)$ & NT & NT \\
\hline $\begin{array}{l}\text { Bag-4 } \\
\text { IMG-152 }\end{array}$ & $74 \pm 2.5(n=3)$ & $47 \pm 10(n=3)$ & $77 \pm 2.9(n=3)$ & $26 \pm 5.2(n=3)$ & $75 \pm 4.7(n=3)$ & $49 \pm 2.5(n=3)$ \\
\hline $\begin{array}{l}\mathrm{Bag}-4 \\
\mathrm{H}-300\end{array}$ & $78 \pm 2.2(n=6)$ & $42 \pm 10(n=6)$ & $78 \pm 0.7(n=6)$ & $29 \pm 11.3(n=6)$ & $78 \pm 4.7(n=6)$ & $49 \pm 5.5(n=6)$ \\
\hline $\begin{array}{l}\text { Hsp70 } \\
\text { cmHsp70.1 }\end{array}$ & $82 \pm 8.8(n=6)$ & $34 \pm 9.5(n=6)$ & $60 \pm 9.7(n=6)$ & $37 \pm 3.1(n=6)$ & $68 \pm 11.4(n=6)$ & $38 \pm 5.5(n=6)$ \\
\hline $\begin{array}{l}\text { Hsp40 } \\
\text { SPA-400 }\end{array}$ & $17 \pm 5.5(n=6)$ & $23 \pm 3.8(n=7)$ & $15 \pm 6.5(n=4)$ & $13 \pm 5.1(n=6)$ & $14 \pm 0.8(n=4)$ & $19 \pm 3.4(n=4)$ \\
\hline $\begin{array}{l}\text { Hsp60 } \\
\text { SPA-806 }\end{array}$ & $1.7 \pm 0.0(n=3)$ & $1.1 \pm 0.15(n=3)$ & $1.4 \pm 0.15(n=3)$ & $1.4 \pm 0.6(n=3)$ & $0.7 \pm 0.3(n=3)$ & $2.2 \pm 0.4(n=3)$ \\
\hline $\begin{array}{l}\text { Hsp90 } \\
\text { SPA-830 }\end{array}$ & $2.6 \pm 0.45(n=3)$ & $2.1 \pm 0.7(n=3)$ & $1.7 \pm 0.3(n=3)$ & $1.7 \pm 0.6(n=3)$ & $1.8 \pm 0.5(n=3)$ & $3.1 \pm 1.3(n=3)$ \\
\hline
\end{tabular}


(Figure 2a, left part). Regarding these results, we concluded that nonlethal $\gamma$-irradiation results in an upregulated Hsp70 and Bag-4 membrane expression in carcinoma sublines with initially low expression levels.

These data could be confirmed in pancreas carcinoma sublines Colo+/Colo-, which were generated using the same protocol as described for $\mathrm{CX}+/ \mathrm{CX}$ - sublines. ${ }^{29}$ After cell sorting, about $60 \%$ of the Colo + cells exhibited an Hsp70 membrane-positive phenotype, but only $37 \%$ of the Colocells were found to be Hsp70 membrane-positive (Table 3). With respect to Bag- $4,77 \%$ of the Colo + cells and $26 \%$ of the Colo- cells were membrane-positive, as determined with the antibody IMG-152 (Table 3). This phenotype remained stable in the tumor sublines for at least 30 cell passages. As already shown for $\mathrm{CX}+/ \mathrm{CX}-$, and in contrast to the differences detected in the cell surface expression pattern, the intracellular Hsp70/Bag-4 content was identical in Colo + /Colo- cells (Figure 1b). After nonlethal $\gamma$-irradiation, the percentage of Hsp70 (37-58\%, $P<0.04)$ and Bag-4 (26-60\%, $P<0.02)$ increased selectively in Colo- but not in Colo + carcinoma cells (Figure $2 \mathrm{~b}$, left graph). Similar to $\mathrm{CX}$ - colon carcinoma cells, also the protein density of Hsp70 $(P<0.03)$ and Bag-4 $(P<0.04)$ on a single cell level was elevated in Colo- cells (Figure 2b, right graph). No cell surface expression was determined using antibodies directed against the $\mathrm{N}$-terminal region of Bag-4 or against Bag-1 with epitopes residing in the C- or N-terminus (Table 3).

A comparison of the amount of plasma membrane-bound Hsp70 and Bag-4 in untreated and irradiated ( $1 \times 10 \mathrm{~Gy})$ $\mathrm{CX}+/ \mathrm{CX}-$ (Figure 2a) and Colo + /Colo -(Figure 2b) sublines was in line with data from flow cytometry (Figure 2). Again a significant increase in the amount of Hsp70 and Bag-4 was predominantly found in $\mathrm{CX}$ - and Colo- tumor sublines after nonlethal irradiation (Figure 3). That of $\mathrm{CX}+$ and Colo + tumor sublines remained unaltered and high after identical treatment. Regarding these results, derived from two independent carcinoma cell systems, we speculated about a coregulated expression of Hsp70/Bag-4 on the plasma membrane of tumor cells. To further address this question, HeLa cervix carcinoma cells were transfected either with mouse Bag-4, which is highly homologous to human Bag-4, or with neo vector, as a control. The cytosolic amount of Hsp70 and Bag-4 in untreated and irradiated HeLa cells is illustrated in Figure 4. Compared to neo-transfected (Figure 4, lower graph) or untransfected (data not shown) HeLa cells, Bag-4transfected HeLa cells exhibited a more than six-fold increase in cytosolic Bag-4, if related to tubulin. Nevertheless, this Bag4 overexpression did not affect cytosolic Hsp70 content (Figure 4, upper graph). Also, after nonlethal $\gamma$-irradiation, the cytosolic Hsp70 and Bag-4 levels remained unaltered when compared to nonirradiated cells (Figure 4).

Striking differences were detected with respect to membrane-bound Hsp70 and Bag-4 in the HeLa cell system. As shown in Figure 5 (left part) and Table 3, the number of Hsp70 membrane-positive cells in Bag-4-transfected HeLa cells was $68 \%$ and that in neo-transfected cells was $38 \%$. Differences in Bag-4 membrane expression on HeLa cells were as follows: Bag-4-transfected, 78\%; neo-transfected, 49\%. Following $\gamma$-irradiation, a significant increase in the percentage of $\mathrm{Hsp} 70$ $(P<0.04)$ and Bag-4 $(P<0.001)$ positivity was selectively
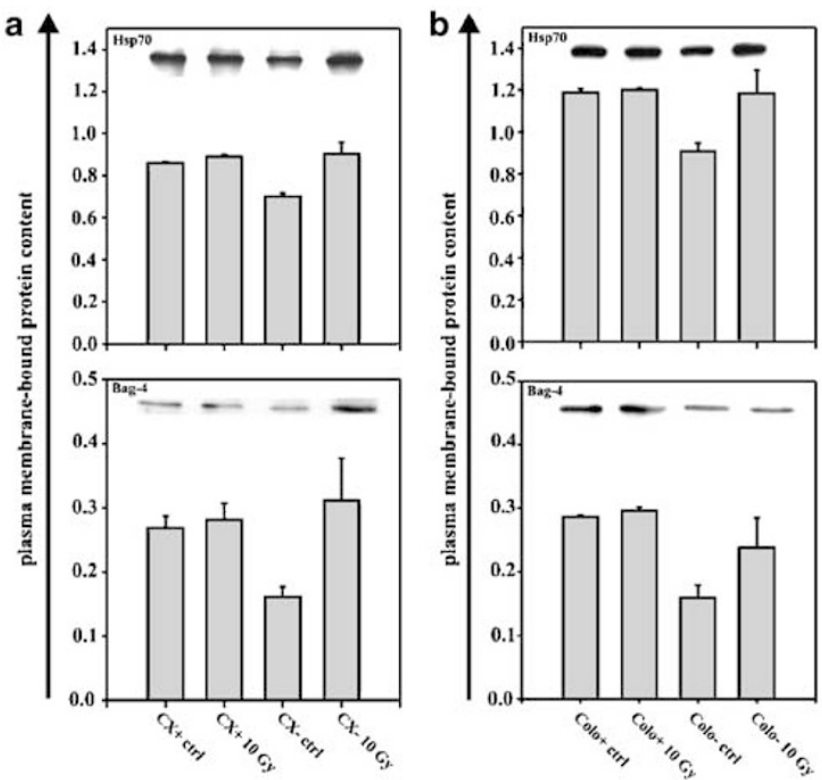

Figure 3 Amount of plasma membrane-bound Hsp70 and Bag-4 increased in $\mathrm{CX}$ - and Colo - tumor sublines after nonlethal $\gamma$-irradiation. Plasma membranes were purified from untreated (ctrl) and irradiated (10 Gy) CX+/CX-(a) and Colo + /Colo - (b) tumor sublines $\left(50 \times 10^{6}\right.$ cells each). Equal amounts $(10 \mu \mathrm{g})$ of plasma membrane-bound proteins were subjected to a $10 \%$ SDS-PAGE and blotted onto nitrocellulose membranes. One representative Western blot analysis using Hsp70 and Bag-4 antibodies and histograms showing mean values \pm S.E. of three independent experiments are illustrated. Increase in the protein amount of Hsp70 and Bag-4 on $\mathrm{CX}-$ and Colo- sublines after irradiation was statistically significant $(P<0.05)$

observed in HeLa neo cells (Hsp70: 38-58\%; Bag-4: 49$76 \%)$. As already shown for $\mathrm{CX}-$ and Colo- cells, concomitant with the increase in the percentage of positively stained cells, the protein density per cells of Hsp70 $(P<0.03)$ and Bag-4 $(P<0.05)$ were also found to be elevated in neotransfected HeLa cells (Figure 5, right part). Purified plasma membrane preparations of neo-transfected and Bag-4-transfected HeLa cells were in line with these findings (data not shown). Taken together, $\gamma$-irradiated HeLa neo cells reacted similar to CX - and Colo- cells with a significant increase in the percentage and protein density of Hsp70/Bag-4 on the cell surface, whereas Bag-4-transfected cells reacted like $\mathrm{CX}+$ and Colo + cells. It is worth mentioning that untransfected HeLa cells behaved identical to neo-transfected cells (data not shown).

\section{Cell surface expression of Hsp70 and Bag-4 is similarly upregulated in tumor cells with initial low expression levels by $\gamma$-irradiation}

To test whether upregulation of the Hsp70 and Bag-4 membrane expression might be associated, multiparameter flow cytometry analysis was performed using FITC-conjugated Hsp70 and PE-conjugated Bag-4 antibodies. In Figure $6 \mathrm{a}-\mathrm{c}$, horizontal and vertical lines mark the results derived from staining with isotype-matched control antibodies. Under 

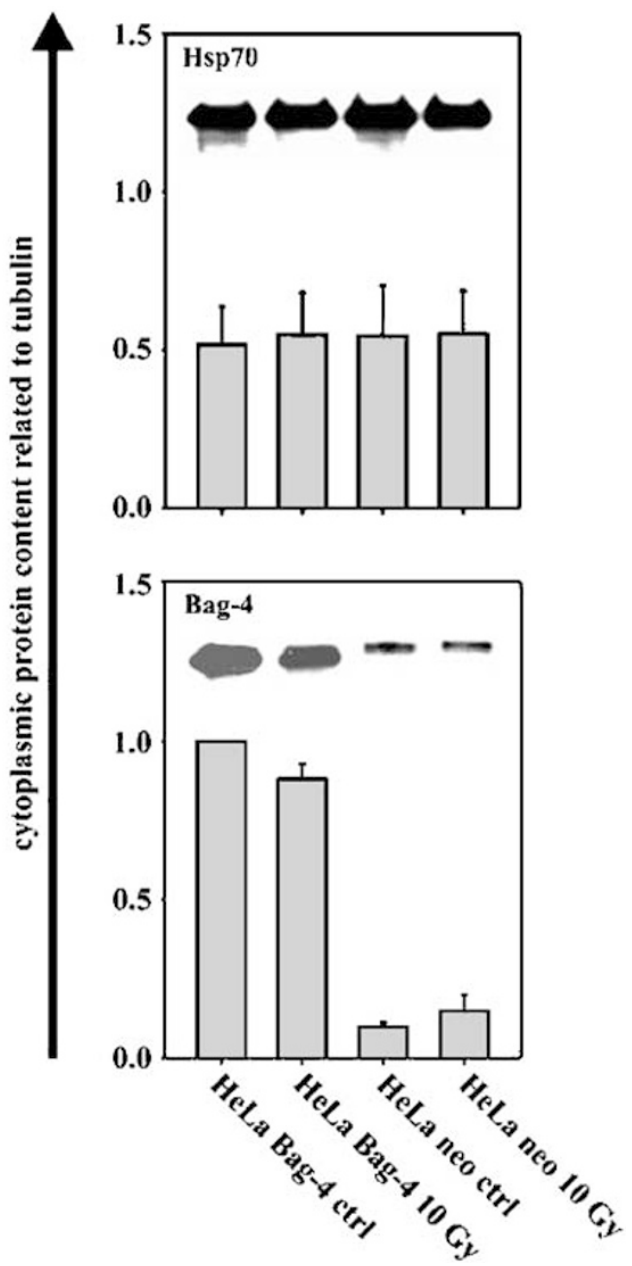

Figure 4 Cytosolic Hsp70 and Bag-4 levels in Bag-4 overexpressing or neotransfected HeLa cervix carcinoma cells remained unaltered after nonlethal $\gamma$ irradiation. HeLa cervix carcinoma cells transfected with mouse Bag-4 revealed a more than six-fold increase in cytosolic Bag-4 levels as compared to neotransfected or untransfected (data not shown) cells. HeLa Bag-4- and neotransfected carcinoma cells were maintained either untreated (ctrl) or were irradiated $(1 \times 10 \mathrm{~Gy})$. After a recovery period of $24 \mathrm{~h}$, cell lysates were prepared and equal protein amounts $(10 \mu \mathrm{g})$ were run on a $10 \%$ SDS-PAGE, and transferred to nitrocellulose membranes. Western blots were stained with Hsp70and Bag-4-specific antibodies (Table 1). Data show one representative Western blot analysis and histograms of four independent experiments \pm S.E., related to tubulin

physiological conditions (ctrl), an Hsp70/Bag-4 double-positive cell population, in the upper right corner of each graph, was visible only in $\mathrm{CX}+$, Colo + , and HeLa Bag-4-transfected cells (upper part). After nonlethal $\gamma$-irradiation $(1 \times 10 \mathrm{~Gy})$, the percentage of double-positive cells was not elevated significantly in CX + (Figure 6a: 71-77\%), Colo + (Figure 6b: 65-75\%), and HeLa Bag-4-transfected (Figure 6c: 73-74\%) carcinoma cells. In contrast, in initially low-expressing CX- (Figure 6a: 35-73\%), Colo- (Figure 6b: 34-52\%), and HeLa neo-transfected (Figure 6c: 49-73\%) cells, the amount of Hsp70/Bag-4 double-positive cells was drastically enhanced after $\gamma$-irradiation. This is illustrated in the lower parts of Figure $6 \mathrm{a}-\mathrm{c}$ (ctrl versus $10 \mathrm{~Gy}$ ) by a shift of the cell
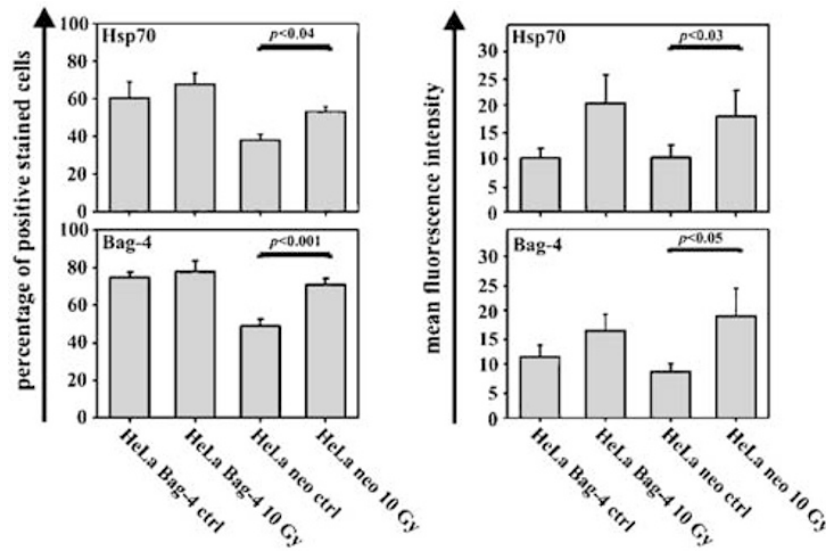

Figure 5 Cell surface expression of Hsp70 and Bag-4 was upregulated on neotransfected HeLa cells after nonlethal $\gamma$-irradiation. The percentage of positive cells (left part) and the mean fluorescence intensity (right part) of Hsp70 and Bag4 were determined by flow cytometry on untreated (ctrl) and irradiated (1 × 10 Gy) HeLa Bag-4-/HeLa neo-transfected carcinoma cells, using Bag-4specific antibodies recognizing the C-terminally localized BAG domain (Table 1). Histograms represent mean values of seven independent experiments \pm S.E.; significant differences are indicated as $P$-values

population from the lower left corner to the upper right corner. These data confirmed the results obtained by single antibody staining (Figures 2 and 5), and also provide a hint that membrane expression of Hsp70 and Bag-4 might be coregulated in tumor cells with initially low membrane expression levels.

\section{Hsp70 and Bag-4 are colocalized on the cell surface of tumor cells}

To further test this hypothesis, immunocytochemistry studies were performed using a two-color overlay staining technique. Figure 7a represents a typical image of a Bag-4 PE single staining in red, and Figure 7b an Hsp70 FITC single staining in green. Orange dots in the overlay of both staining patterns revealed that most Hsp70 and Bag-4 molecules on the plasma membrane are colocalized (Figure 7c). Light microscopic analysis, as indicated in Figure $7 \mathrm{~d}$, showed regular cell morphology of the Hsp70/Bag-4 double-positive tumor cells used in these assays. The corresponding isotype-matched negative control staining is shown in Figure $7 \mathrm{e}-\mathrm{g}$. A higher magnification of a typical Hsp70/Bag-4 costaining pattern and the corresponding light microscopic view are illustrated in Figure $7 \mathrm{i}$ and $\mathrm{j}$.

\section{Hsp70/Bag-4 are associated with Hsp40 on the plasma membrane of $\mathrm{CX}+$ and Colo + tumor sublines}

In the cytosol, Hsp70 frequently operates in concert with several co-chaperones including Hsp40, Hsp60, and Hsp90. ${ }^{2}$ To test whether one of these chaperones might be associated with Hsp70/Bag-4 on the cell surface of tumor cells, flow cytometric analyses were performed. As summarized in 
a

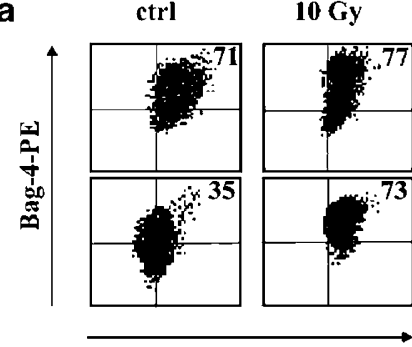

Hsp70-FITC

b

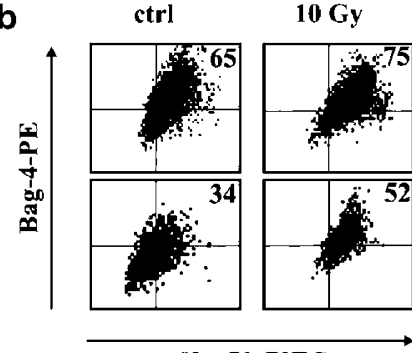

Hsp70-FITC

c

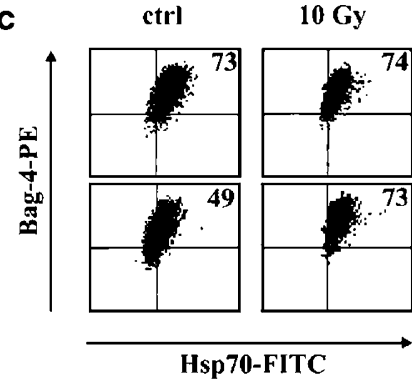

$\mathbf{C X}+$

CX-

Colot

Colo-

\section{HeLa Bag-4}

\section{HeLa neo}

Figure 6 Following nonlethal $\gamma$-irradiation, the Hsp70 and Bag-4 doublepositive cell population is upregulated in $\mathrm{Hsp} 70 / \mathrm{Bag}-4$ low-expressing carcinoma sublines. Different carcinoma sublines $\mathrm{CX}+/ \mathrm{CX}-(\mathbf{a})$, Colo $+/$ Colo- (b), and HeLa Bag-4/HeLa neo (c), kept either untreated (ctrl) or irradiated (10 Gy), were double-positively stained with Hsp70 FITC and Bag-4 PE and analyzed by multiparameter flow cytometry. Values for isotype-matched control antibodies for each individual cell type, either untreated (ctrl) or after irradiation (10 Gy), are marked as vertical and horizontal lines. The percentages of Hsp70/Bag-4 doublepositively stained cells corrected for the nonspecific staining using isotypematched control antibodies are indicated as numbers in the upper right corner of each graph. Only 7-AAD-negative, viable cells were gated. Dot blots illustrate one representative staining pattern out of three identical experiments

Table 3, a positive cell surface staining was detectable only for Hsp40, but not for other HSPs including Hsp60 and Hsp90. No significant differences in the percentages of Hsp40-positive CX +/CX-, Colo + /Colo-, and HeLa Bag-4/HeLa neo-transfected cells were found (Table 3 ). Following irradiation, Hsp40 expression was not upregulated significantly (data not shown).

Immunoprecipitation experiments using purified plasma membranes derived from $\mathrm{CX}+/ \mathrm{CX}$ - cells confirmed these findings. As shown in Figure 8 (lower right part), Hsp40 protein could be immunoprecipitated by Hsp40 antibody-coupled beads from plasma membranes prepared from $\mathrm{CX}+$ and CX - tumor cells. As expected, Hsp70 protein could be precipitated selectively from plasma membranes of $\mathrm{CX}+$ tumor sublines but not from that of their Hsp70-negative
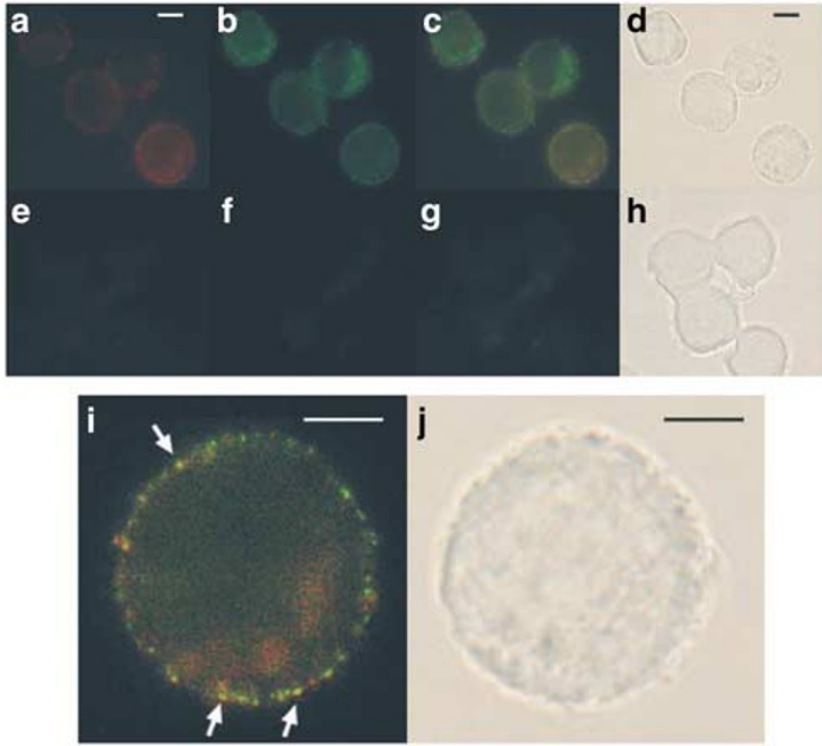

Figure 7 Hsp70/Bag-4 are colocalized on the surface of double-positive tumor cells. CX + cells were stained at $4^{\circ} \mathrm{C}$ either with the Bag-4 PE- (a), the Hsp70 FITC- (b) conjugated or an isotype-matched control antibody in both colors $(\mathbf{e}, \mathbf{f})$. Cells were mounted on slides and analyzed in a fluorescence microscope. Bag-4 positively stained cells are visible in red and Hsp70 positively stained cells in green. Colocalization of Hsp70 and Bag-4 in an overlay is visible as orange spots (c). (i) A higher magnification of an Hsp70/Bag-4 double-positive stained cell. Corresponding light microscopic views are shown in (d), (h), and (j). Experiments were repeated at least four times and identical results were obtained for Colo + cells; scale bar, $5 \mu \mathrm{m}$

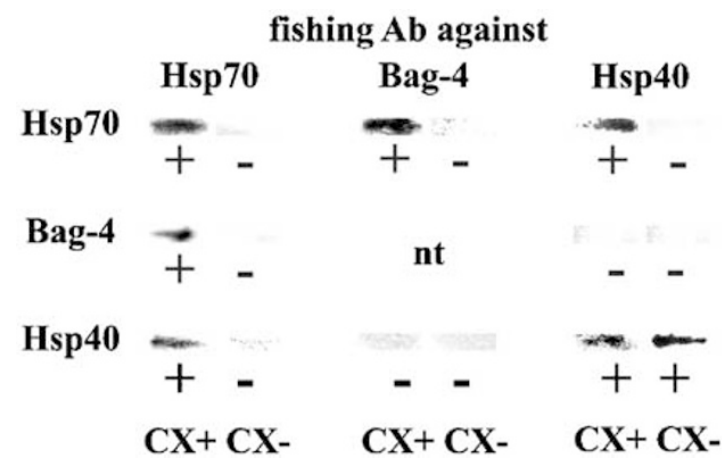

Figure 8 Co-immunoprecipitation of Hsp70, Bag-4, and Hsp40 from purified plasma membrane extracts of $\mathrm{CX}+/ \mathrm{CX}$ - tumored cells. Purified plasma membranes were incubated with beads couple either with Hsp70 (left graph), Bag-4 (middle graph), or Hsp40 (right graph) antibodies. Precipitates were stained with Hsp70 (cmHsp70.1)-, Bag-4 (IMG-152)-, and Hsp40 (SPA-400)specific antibodies. One representative Western blot analysis of two with identical results is illustrated; results are summarized as '+ ' and '-' below each graph; nt, not tested

counterparts (Figure 8, upper part). Interestingly, Hsp70 was found also in precipitations of CX + plasma membranes, using Bag-4 and Hsp40 antibody-coupled beads. These data indicated that Hsp70 might be associated with Bag-4 and Hsp40 on the plasma membrane of CX + cells. However, an interaction of Hsp70, Bag-4, and Hsp40 could be excluded due to the fact that Bag-4 and Hsp40 antibody-coupled beads 
did not co-immunoprecipitate Hsp40 and Bag-4 together with Hsp70 from CX + plasma membranes (Figure 8). Similar results were obtained when membranes of Colo + cells were used (data not shown).

In summary, these data indicated that Hsp70 was associated either with Bag-4 or Hsp40 on the plasma membrane of $\mathrm{CX}+$ and Colo + tumor sublines. In CX - tumor sublines, Hsp40 was found on the cell surface also in the absence of Hsp70 and Bag-4, as determined by flow cytometry (Table 3) and immunoprecipitation (Figure 8). Other HSPs including $\mathrm{Hsp60}$ and $\mathrm{Hsp} 90$ were neither detectable on the cell surface of Hsp70 membrane-positive nor on their negative counterparts (Table 3 ).

\section{Hsp70/Bag-4 cell surface expression confers protection against $\gamma$-irradiation-induced effects}

Functional consequences of nonlethal $\gamma$-irradiation in tumor sublines with differential Hsp70/Bag-4 and Hsp70/Hsp40 membrane expression pattern were analyzed in a standard $\left[{ }^{3} \mathrm{H}\right]$ thymidine assay. Irrespective of the treatment, after $12 \mathrm{~h}$, all cells became plastic adherent (data not shown), thus indicating that anoikes was not responsible for the differential cell growth. Representative images of cell cultures photographed after $48 \mathrm{~h}$ are shown in the upper part of Figure $9 \mathrm{a}-\mathrm{c}$. Growth rates of untreated Hsp70/Bag-4 high-expressing carcinoma cells $(\mathrm{CX}+$, Colo,$+ \mathrm{HeLa}$ Bag-4) and their lowexpressing counterparts ( $\mathrm{CX}-$, Colo-, HeLa neo) were comparable, as depicted by light microscopic analysis and by $\left[{ }^{3} \mathrm{H}\right]$ thymidine uptake (Figure $9 \mathrm{a}-\mathrm{c}$ ). Following irradiation at $1 \times 10 \mathrm{~Gy}$ and a $48 \mathrm{~h}$ recovery period, proliferation was reduced in all cell types. However, a comparison of irradiated $\mathrm{CX}+/ \mathrm{CX}-$, Colo + Colo- , and HeLa Bag-4/HeLa neo cells revealed that Hsp70/Bag-4 and Hsp70/Hsp40 high-expressing carcinoma cells appeared to be better protected against irradiation-induced growth reduction, as compared to their low-expressing counterparts. After irradiation at $1 \times 10 \mathrm{~Gy}$, growth reduction was $40 \%$ in CX + cells, $54 \%$ in Colo + cells, and $22 \%$ in HeLa Bag-4-transfected cells. In CX-, Colo-, and HeLa neo-transfected cells, growth reduction was significantly elevated: $72 \%\left({ }^{\star} P<0.00007, n=5\right)$, and $69 \%\left({ }^{\star} P<0.00003\right.$, $n=12)$, and $67 \%\left({ }^{\star} P<0.00007, n=8\right)$, respectively.

It was known that growth inhibition mediated through irradiation is due to a $\mathrm{G} 2 / \mathrm{M}$ cell cycle arrest. Therefore, in addition to the $\left[{ }^{3} \mathrm{H}\right]$ thymidine uptake assay, cell cycle analyses were performed before and after identical treatment conditions. The typical irradiation-induced G2/M arrest was more pronounced in CX-(G2/M: 69 versus $53 \%, n=3)$, Colo(G2/M: 55 versus $43 \%, n=4)$, and HeLa new cells (G2/M: 63 versus $32 \%, n=4$ ), as compared to their Hsp70/Bag-4 highexpressing partner cell lines. These data further supported the results obtained by $\left[{ }^{3} \mathrm{H}\right]$ thymidine uptake assays.

\section{$\gamma$-Irradiation-induced Hsp70/Bag-4 membrane expression is associated with an increased sensitivity toward activated NK cells}

Previously, we demonstrated that membrane-bound Hsp70 provides a target structure for Hsp70 peptide-activated NK cells. ${ }^{17}$ Following physical (heat) or chemical (ET-18-OCH3, paclitaxel, vincristinsulfate) stress, the amount of membranebound Hsp70 was increased on the cell surface of tumor cells. ${ }^{19,20,30}$ Concomitantly, an elevated sensitivity to lysis mediated by Hsp70 peptide-activated NK cells was observed. Here, Hsp70 peptide-activated, CD94 positively enriched NK cells were used as effector cells in cytotoxicity assays and tested against untreated and irradiated tumor cells. ${ }^{31}$ As shown in Figure 10, untreated Hsp40 membrane-positive carcinoma sublines with low Hsp70/Bag-4 membrane expression (CX-, Colo-, HeLa neo, filled circles (right part) were lysed less efficiently as compared to their high-expressing counterparts $(\mathrm{CX}+$, Colo + , HeLa Bag-4, filled circles (left part), unless irradiation. After nonlethal $\gamma$-irradiation, lysis of Hsp70/Bag-4-positive CX + , Colo +, and HeLa Bag-4 carcinoma cells remained unaltered and high (open circles, left part). In contrast, lysis of irradiated $\mathrm{CX}-$, Colo-, and HeLa neo carcinoma cells, with initially low Hsp70/Bag-4 expression, was significantly enhanced in a dose-dependent manner (open circles, right part). CD3 positively enriched $\mathrm{T}$ cells neither showed significant lysis of untreated nor irradiated tumor sublines even after stimulation with Hsp70 peptide (data not shown). Taken together, these data indicated that an irradiation-induced increase in Hsp70/Bag-4 membrane expression (Figures 2 and 5), conferring resistance to $\gamma$ irradiation, corresponded to an enhanced sensitivity toward NK cell-mediated cytotoxicity. By incubation of irradiated carcinoma cells with Hsp70-specific antibody cmHsp70.1, a significant inhibition of lysis down to the level of Hsp70/Bag-4 low-expressing tumor cells was detected (filled triangles, right and left parts). In contrast, different antibodies directed against Bag-4 (H-300; IMG-152), Hsp40 (SPA-450; SPA400), Hsp60 (SPA-806), and Hsp90 (SPA-830) did not affect the cytolytic activity of NK cells (data not shown). These data indicated that although Bag-4 and $\mathrm{Hsp} 40$ were present on the cell surface of tumor cells, they are not involved in the recognition mediated by NK cells.

\section{Discussion}

Radiation is frequently used in cancer therapy, either as a single regimen or in combination with cytostatic drugs. However, radiation-resistant tumor clones limit the therapeutic efficacy. High cytosolic Hsp70 levels could be correlated with protection against apoptotic cell death induced by stress or exogenous compounds. ${ }^{4,32}$ Here, the effects of nonlethal $\gamma$-irradiation were analyzed in three independent carcinoma cell systems, with initially divergent $\mathrm{Hsp} 70$ membrane expression pattern. Apart from Hsp70, members of the BAG family are known to be involved in the regulation of programmed cell death. $^{8,32}$ Six different members of the Bag family could be identified in humans, all sharing a conserved BAG domain and a variable $\mathrm{N}$-terminus. Four of the six members, Bag-1, -3, -4, and -6 , interact with the ATPase domain of Hsp70 and Hsc70. ${ }^{33,34}$ In addition to Hsp70, BAG proteins also bind to cell surface receptors. Interaction of Bag-1M isoform in concert with $\mathrm{Hsp} 70 / \mathrm{Hsc70}$ to retinoic acid receptors, glucocorticoid, estrogen, and thyroid hormone receptors ${ }^{33-36}$ mediates stress signaling pathways that regulate Raf-1/ERK 

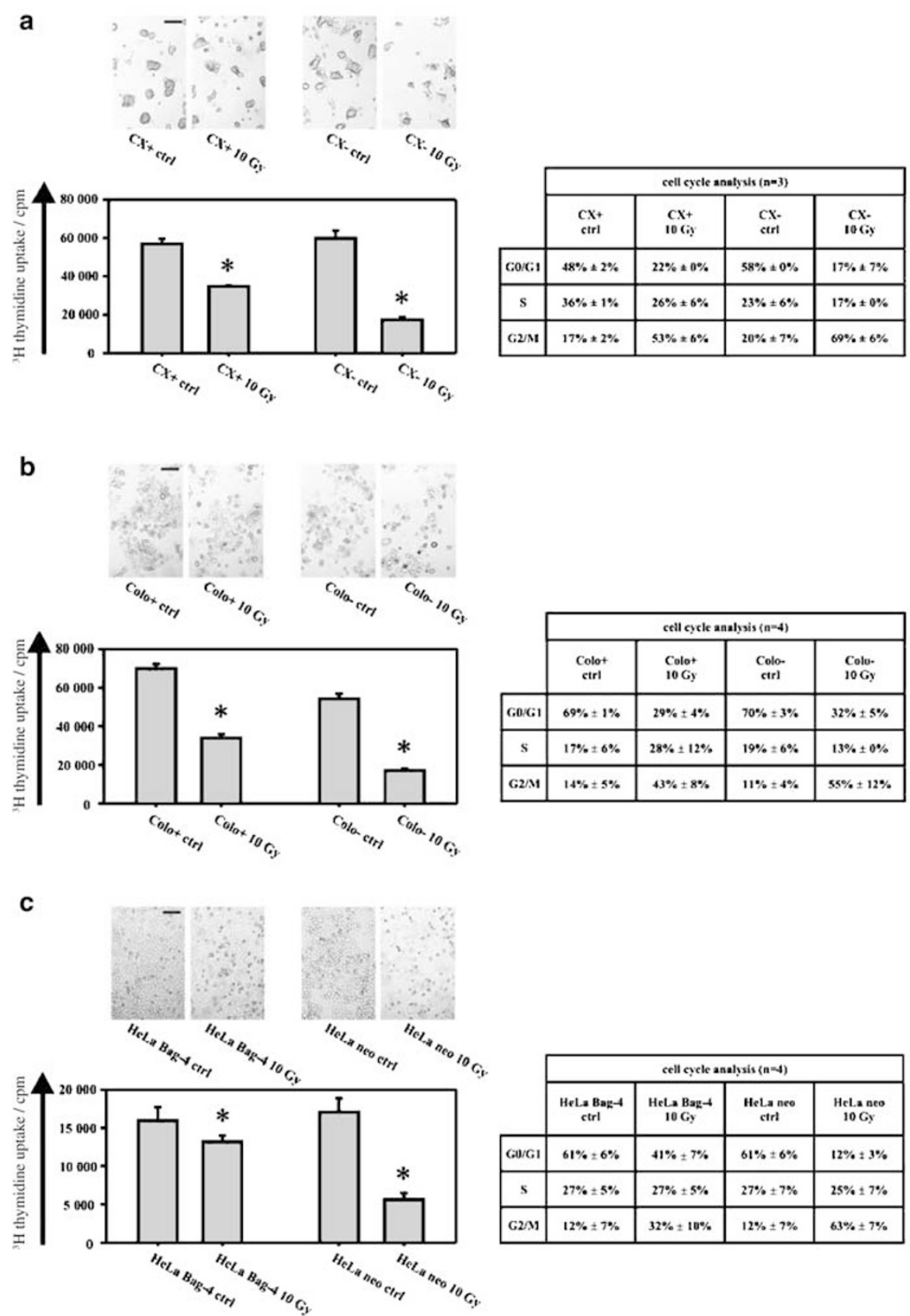

Figure 9 Hsp70/Bag-4 low-expressing carcinoma sublines are more sensitive to $\gamma$-irradiation-induced effects as compared to their high-expressing counterparts. Light microscopic analysis, ${ }^{3} \mathrm{H}$ thymidine uptake, and cell cycle analysis of either untreated (ctrl) or irradiated $(1 \times 10 \mathrm{~Gy}) \mathrm{CX}+/ \mathrm{CX}-(\mathbf{a})$, Colo $+/ \mathrm{Colo}-(\mathbf{b})$, and HeLa Bag4/HeLa neo (c) cells are illustrated. Inhibition of cell growth was significantly $\left({ }^{\star} P<0.05\right)$ more pronounced in Hsp70/Bag-4 low-expressing carcinoma cells as compared to their Hsp70-Bag-4 high-expressing counterparts. Results of proliferation assays were repeated 5-12 times. Cell cycle analysis represents mean values of three to four different experiments \pm S.E.; scale bar, $200 \mu \mathrm{m}$

and cell growth. ${ }^{37}$ Bag-3 forms an EGF-regulated ternary complex with phospholipase $\mathrm{C}-\gamma$ and $\mathrm{Hsp} / 70 / \mathrm{Hsc} 70$ in human melanoma cells. ${ }^{38,39}$ Bag-6, first described in Xenopus, interacts with apoptosis-inducing factor reaper in Drosophila cell. ${ }^{40} \mathrm{Hsc70}$ (under physiological conditions) and Hsp70 (following stress) have been found to serve as regulators coupling function of BAG proteins to plasma membranelocalized receptors. We and others determined cell mem- brane localization of Hsp70 in tumor cells. ${ }^{17,18}$ Together with the finding that in the cytosol Hsp70 binds to members of the BAG family, it was conceivable that also on the plasma membrane both molecules are interacting and thus might fulfill regulatory functions in apoptotic cell death.

In the present study, we concentrated on the interaction of Hsp70 and Bag-4, also termed SODD, since other members of the BAG family were not detectable on the cell surface of 


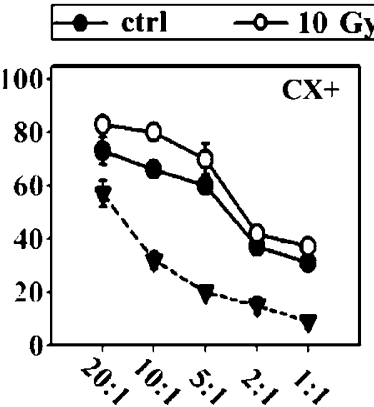

$\bullet \bullet \cdot \cdot 10 \mathrm{~Gy}+\mathrm{Hsp70} \mathrm{Ab}$
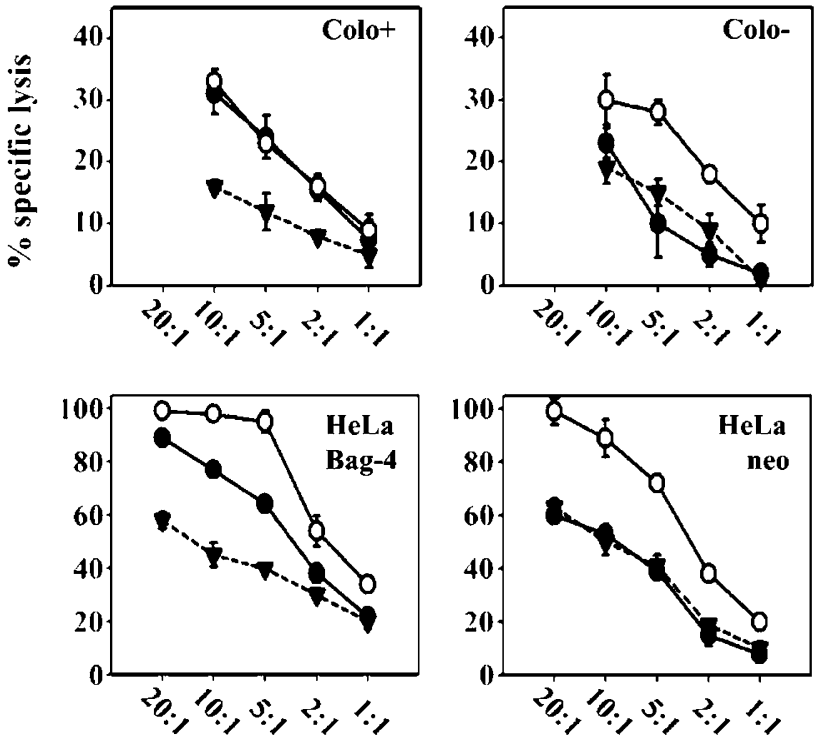

E:T ratio

Figure $10 \quad \gamma$-Irradiation-induced increase in Hsp70/Bag-4 on the plasma membrane enhances the sensitivity against the cytolytic attack mediated by Hsp70 peptide-activated NK cells. Cytolytic activity of CD94-enriched, Hsp70activated NK cells was determined in a CML assay against Hsp70/Bag-4 high(CX +, HeLa Bag-4, left part) and low-expressing (CX-, Colo-, HeLa neo, right part) carcinoma sublines, either untreated (closed circles) or after $\gamma$-irradiation (open circles). Hsp70 specificity was demonstrated by blocking assays using the Hsp70-specific monoclonal antibody cmHsp70.1 (dotted line). Specific lysis was determined at different $E: T$ ratios ranging from $20: 1$ to $1: 1$ for $C X+/ C X$ - cells and HeLa Bag-4/HeLa neo cells, and 10:1 to $1: 1$ for Colo +/Colo- cells; percentage spontaneous release for each target cell was less than $20 \%$; data represent mean values of two independent experiments

tumor cells. Although our tumor sublines differed significantly in their capacity to present Hsp70 cell surface, no alterations were observed in cytosolic Hsp70 content. Even after nonlethal $\gamma$-irradiation, the cytosolic amount of Hsp70 remained unchanged. Comparable results were obtained for cytosolic Bag-4.

In contrast to the cytoplasm, the amount of membranebound Hsp70 was significantly upregulated in tumor sublines with initially low Hsp70 cell surface expression following $\gamma$-irradiation. Interestingly, the Hsp70 membrane-positive phenotype was associated with a Bag-4 cell surface expression. Other members of the BAG family, including Bag-1 $\mathrm{M}$ and Bag1, were not found on the cell surface. Colocalization of
Hsp70 and Bag-4 was shown by two-color flow cytometry and immunohistochemistry. These data led us to the hypothesis that Hsp70/Bag-4 protein complexes not only exist in the cytosol but also in the plasma membrane.

We found a positive cell surface staining of Bag-4 only with antibodies reacting with the $\mathrm{C}$-terminus, known to interact with the ATPase domain of Hsp70; antibodies directed against the $\mathrm{N}$-terminus were unable to detect membrane-bound Bag-4. This could be due to the fact that the $\mathrm{N}$-terminal domain of Bag-4 is masked by Hsp70 bound to Bag-4. On the other hand, this might also provide an explanation for the finding that antibodies directed against the ATPase domain of Hsp70 were unable to recognize cell membrane-bound Hsp70. ${ }^{41}$

It has been reported that Hsp70 associated with Bag-4 binds to the death domain of TNFR1 or DR3 and thus prevents self-aggregation to functional trimers initiating caspasedependent apoptotic cell death. ${ }^{42}$ Therefore, we hypothesized that membrane-bound Hsp70/Bag-4 might also be linked to the cytosolic domain of TNFR1. However, neither CX $+/ C X-$ nor Colo + /Colo- carcinoma sublines exhibited TNFR1 or DR3 on their cell membranes. Furthermore, incubation of the carcinoma cells with TNF- $\alpha$ either alone or in combination with cycloheximid did not induce apoptosis (data not shown). Regarding these results, we speculated about a TNFR1/DR3independent cell surface translocation of Hsp70/Bag-4. Hsp70 also plays a pivotal role in cell cycle regulation. Treatment of tumor cells with Hsp70 antisense oligomers resulted in inhibition of proliferation and in initiation of apoptosis in tumor cell lines. ${ }^{4,43}$ It has been suggested that overexpression of $\mathrm{Hsp} 70$ reduced radiation-induced cell cycle arrest in the G2/M phase. We provide evidence that not only cytosolic but also cell membrane-bound Hsp70/Bag-4 proteins might be involved in protection against irradiationinduced effects. In unstressed cells, the proliferative capacity was comparable in Hsp70 high- and low-expressing tumor sublines. In contrast, following nonlethal irradiation, Hsp70/ Bag-4 membrane localization appeared to be more resistant to growth arrest.

Screening for co-chaperones of Hsp70 on the cell surface revealed that $\mathrm{Hsp} 40$ was present on the cell surface of all tumor sublines, either in association with Hsp70 or alone. Coimmunoprecipitation studies led us to the hypothesis that in Hsp70 membrane-positive tumor sublines Hsp40 might compete with Bag-4 for binding to the ATPase domain of Hsp70. Regarding these results, we addressed the question as to whether Bag-4 or Hsp40 might be relevant as a target structure for the cytolytic attack mediated by NK cells. Previously, a 14-mer sequence, residing in the C-terminal substrate binding domain of Hsp70, was identified as the extracellular localized part of Hsp70 on tumor cells. ${ }^{30}$ Similar to full-length recombinant Hsp70 protein, this peptide was found to stimulate the cytolytic activity of NK cells against Hsp70 membrane-positive tumor cells. ${ }^{31}$ Affinity chromatography revealed that selectively $\mathrm{Hsp} 70$ protein and $\mathrm{Hsp} 70$ peptide facilitated binding and uptake of granzyme $B$ into Hsp70 membrane-positive tumor cells. The mechanism of lysis after contact of NK cells with Hsp70 was identified as granzyme B-mediated apoptosis. ${ }^{44}$ These data indicated that only Hsp70 or a peptide derived thereof, but not Bag-4 and Hsp40, provided the target structure for NK cell-mediated 
lysis. T lymphocytes neither responded to Hsp70 protein nor to Hsp70 peptide with an increased cytolytic activity.

Recently, several cell surface molecules, including CD40 on B cells, ${ }^{45}$ CD14 and toll-like receptors on monocytes and dendritic cells, ${ }^{46}$ and CD91 on macrophages, ${ }^{47}$ were discussed as potential receptors for HSPs on immunoregulatory cells. The interaction of NK cells with Hsp70 and Hsp70 peptide was found to be mediated through the C-type lectin receptor CD94. ${ }^{48}$

In the present study, we elucidated a dual role for membrane-bound Hsp70, Bag-4, and Hsp40 in radiotherapy. On the one hand, tumor sublines expressing high amounts of Hsp70/Bag-4 and Hsp70/Hsp40 on their cell surface were better protected against $\gamma$-irradiation-induced effects, as compared to their low-expressing counterparts, and thus might confer radioresistance. On the other hand, these tumor cells provided ideal targets for the cytolytic attack mediated by Hsp70 peptide-activated NK cells. Blocking studies clearly demonstrated that selectively Hsp70, but neither Bag-4- nor Hsp40-specific antibodies, had the capacity to inhibit NK cellmediated tumor cell lysis. Together with the finding that the cytolytic capacity of NK cells could be efficiently stimulated by addition of recombinant Hsp70 protein and Hsp70 peptide in the absence of Bag-4 and Hsp40, we concluded that Hsp70 alone is sufficient to sensitize tumor cells for NK cell-mediated lysis. ${ }^{30,31}$

Since an Hsp70 membrane-positive phenotype was frequently found in patient-derived tumor biopsies after in vivo irradiation, ${ }^{49}$ it is conceivable that these patients might profit from Hsp70-activated NK cells that support the elimination of radiation-resistant tumor cells.

\section{Materials and Methods}

\section{Cells and cell culture}

The human colon carcinoma sublines $C X+$ and $C X$ - generated from the parental cell line CX2 (Tumorzellbank, DKFZ Heidelberg, Germany) by cell sorting, using the mouse anti-human Hsp70-specific monoclonal antibody (C-terminus, $\mathrm{aa}_{450-463}, \mathrm{cmHsp} 70.1$, IgG1, multimmune $\mathrm{GmbH}$, Regensburg, Germany), were cultured in RPMI 1640 medium (Gibco, Eggenstein, Germany) supplemented with 10\% heat-inactivated FCS (Gibco), 1\% antibiotics (penicillin/streptomycin, Gibco), and $2 \mathrm{mM}$ L-glutamine (Gibco). The human pancreas carcinoma sublines Colo + and Colo- were sorted from the original cell line Colo 357 (CAMR Centre for Applied Microbiology \& Research, Salisbury, Wiltshire, UK) following the protocol described for $\mathrm{CX}+/ \mathrm{CX}-$ cells. $^{29}$ Growth conditions of pancreas and colon carcinoma sublines were comparable. Exponential cell growth was maintained by regular cell passages. Every 3 days, cells were trypsinized for $1 \mathrm{~min}$ with trypsin/EDTA (Gibco) and single-cell suspensions were seeded at a constant cell density of $0.5 \times 10^{6}$ cells in $5 \mathrm{ml}$ medium in T25 ventilated small culture flasks (Greiner, Nuertingen, Germany).

The human cervix carcinoma cell line HeLa was stably transfected either with an expression vector harboring mouse Bag-4 cDNA (pcDNASODD, access code Q8Cl61, kindly provided by Dr. R Endres, Klinikum MRI, TU-Munich) or with the corresponding control vector (neo). DNA $(8 \mu \mathrm{g})$ was electroporated into $5 \times 10^{6}$ cells using a BioRad gene pulser ( $750 \mathrm{~V}, 25 \mu \mathrm{F}, 200 \Omega, 0.4 \mathrm{~cm}$ cuvettes), and cells were selected in G418 $\left(0.3 \mathrm{mg} / \mathrm{ml}\right.$, Calbiochem, San Diego, CA, USA) containing medium. ${ }^{50}$
Individual subclones stably overexpressing mouse Bag-4 were isolated and cultured, as described above.

Plating efficiencly, doubling time, and protein content in Hsp70 highand low-expressing CX $+/ C X-$, Colo $+/$ Colo-, and HeLa Bag-4/HeLa neo cells were comparable under physiological conditions.

\section{$\gamma$-Irradiation}

Exponentially growing carcinoma cells were exposed to $\gamma$-irradiation, delivered by a ${ }^{137} \mathrm{Cs}$ source at a dose rate of $1 \mathrm{~Gy}$ per $10 \mathrm{~s}$, on day 2 following cell passage, either fractionated $(2 \times 2$ to $5 \times 2 \mathrm{~Gy})$ or with single doses of $1 \times 10$ and $1 \times 20$ Gy. Cell viability was determined in the adherent and nonadherent cell population by Trypan blue exclusion assays using light microscopy and by Annexin-V-FITC staining on a flow cytometer (FACSCalibur, Becton Dickinson, Heidelberg, Germany).

\section{Plasma membrane preparation}

Plasma membranes were prepared from $50-100 \times 10^{6}$ tumor cells, either untreated or following nonlethal irradiation. ${ }^{51}$ After trypsinization, cells were rinsed in $1 \mathrm{ml}$ ice-cold buffer $\left(0.01 \mathrm{M}\right.$ Tris- $\left.\mathrm{HCl}, 5 \mathrm{mM} \mathrm{MgCl}_{2}, \mathrm{pH} 7.4\right)$ and pelleted by centrifugation $\left(500 \times g, 4^{\circ} \mathrm{C}\right)$. The cell pellets were resuspended in ice-cold Dounce buffer (Tris- $\mathrm{HCl}, \mathrm{pH} 7.6,0.5 \mathrm{mM} \mathrm{MgCl}_{2}$ ) and homogenized by 30 strokes in a chilled Dounce homogenizer with a tight-fitting pestle. After adding tonicity restoration buffer $(10 \mathrm{mM}$ Tris- $\mathrm{HCl}$, $0.5 \mathrm{mM} \mathrm{MgCl}, 0.6 \mathrm{M} \mathrm{NaCl}, 1 \mathrm{mM}$ PMSF, $1 \mu \mathrm{g} / \mathrm{ml}$ apoprotinin), broken cells were examined in a phase-contrast microscope. After centrifugation $\left(500 \times g, 4^{\circ} \mathrm{C}, 5 \mathrm{~min}\right)$, EDTA was added to the supernatant at a final concentration of $5 \mathrm{mM}, \mathrm{pH}$ 7.6. After ultracentrifugation for $45 \mathrm{~min}$ at $100000 \times g, 4^{\circ} \mathrm{C}$, plasma membrane pellets were solubilized in PBS buffer $(300 \mathrm{mM} \mathrm{NaCl}, 50 \mathrm{mM}$ Tris-HCl, pH 7.6, $1 \mathrm{mM} \mathrm{PMSF}, 1 \mu \mathrm{g} / \mathrm{ml}$ apoprotinin) by frequent vortexing for $40 \mathrm{~min}$. Insoluble material was discarded by a further centrifugation step at $10000 \times \mathrm{g}$, at $4^{\circ} \mathrm{C}$ for $10 \mathrm{~min}$.

\section{Cell lysate preparation, immunoprecipitation, SDS-PAGE, and Western blot analysis}

Untreated and irradiated cells were washed twice in ice-cold PBS. After trypsinization and another washing step in PBS, cells were counted and cell pellets $\left(5.0 \times 10^{6}\right.$ cells $\left./ \mathrm{ml}\right)$ were diluted in lysis buffer $(120 \mathrm{mM}$ sodium chloride, $40 \mathrm{mM}$ Tris pH 8.0, 0.5\% NP-40).

Hsp70, Bag-4, and Hsp40 antibody (5 $\mu \mathrm{g} / \mathrm{ml})$-conjugated Gamma bind plus protein G-Sepharose beads (Pharmacia) were incubated either with tumor cell lysates or plasma membrane preparations derived thereof for $12 \mathrm{~h}$ at $4^{\circ} \mathrm{C}$ under gentle rotation. After two washing steps, immune complexes were eluted by high salt $(\mathrm{NaCl}, 3 \mathrm{M})$ and equal protein amounts ( $5 \mu \mathrm{g}$ per lane) were subjected to $10 \%$ SDS-PAGE under reducing conditions. $^{52}$ After electrophoresis, proteins were transferred onto nitrocellulose membranes and blotted according to a protocol of Towbin et al. $^{53}$ The following antibodies (Table 1), diluted 1: 1000, were used for Western blot analysis: mouse anti-human Hsp70 (C-terminus, aa $a_{450-463}$, cmHsp70.1, multimmune $\mathrm{GmbH}$, Regensburg, Germany), rabbit antihuman Bag-4/SODD (C-terminus, H-300, Santa Cruz Biotechnology, Santa Cruz, CA, USA), rabbit anti-human Bag-4/SODD (C-terminus, $\mathrm{aa}_{443-457}$, IMG-152, Imgenex, San Diego, CA, USA), goat anti-human Bag-4/SODD (N-terminus, N-19; Santa Cruz Biotechnology), goat antihuman Bag-1 (C-terminus; C-16, Santa Cruz Biotechnology), rabbit antihuman Bag-1 (full length; FL-274, Santa Cruz Biotechnology), mouse anti-human Hsp40 (J domain, SPA-450, Stressgen, British Colombia, 
Canada), mouse anti-human Hsp60 (C-terminus, SPA-806, Stressgen), mouse anti-human Hsp90 (C-terminus, SPA 830, Stressgen), and mouse anti-human tubulin (clone DM1A, Oncogene, Boston, MA, USA). After incubation with the corresponding horseradish peroxidase-conjugated secondary antibodies (DAKO, Glostrup, Denmark), also diluted 1:1000, protein bands were visualized by chemiluminescence (ECL detection kit, Amersham Biosciences, Little Chalfont, UK). Autoradiographs were recorded on X-omat films (Kodak, Stuttgart, Germany). Prestained standard protein markers (Amersham Biosciences) were used for estimating the molecular weights of each protein.

\section{Flow cytometry}

For direct flow cytometry, tumor cells $\left(0.1 \times 10^{6}\right.$ cells per antibody) were counted and incubated either with an FITC-conjugated Hsp70 (cmHsp70.1) or an isotype-matched IgG1 negative control antibody. Following two washing steps and an incubation period of $20 \mathrm{~min}$ with 7-amino-actinomycin D (7-AAD, Becton Dickinson Pharmingen, Heidelberg, Germany), viable cells were analyzed on a FACSCalibur flow cytometer (Becton Dickinson).

For indirect flow cytometry, unconjugated antibodies (diluted 1:100), directed against Bag-4 (H-300, IMG-152), Bag-1 (FL-274, C-16), Hsp40 (SPA-400), Hsp60 (SPA-806), and Hsp90 (SPA-830), were incubated with tumor cells at $4^{\circ} \mathrm{C}$ for $20 \mathrm{~min}$. After two washing steps, cells were incubated with the corresponding PE-conjugated secondary antibody at $4^{\circ} \mathrm{C}$ for another $15 \mathrm{~min}$ in the dark and analyzed as described above.

In a double-staining procedure, cells were incubated sequentially with the different antibodies. A detailed description of the different antibodies is summarized in Table 1.

\section{Light and immunofluorescence microscopy}

Tumor cells, untreated or irradiated, were stained as described for flow cytometry and transferred to glass slides in Fluorescent Mounting Medium (DAKO, Carpinteria, USA). Slides were analyzed for transmission and fluorescence microscopy on a Zeiss Axioscop 2 Scanning microscope (Zeiss, Jena, Germany) equipped with a $\times 100$ (planar) and $a \times 63$ (apochromatic) oil-immersion objective and standard filters. Multiplicative shading corrections were performed using the software Axiovison (Zeiss Vision, Jena, Germany). Photographs of specifically stained cells sections were taken. The localization of Bag-4 was visualized in red (PE) and of Hsp70 in green (FITC). An overlay of red and green is marked in orange.

\section{$\left[{ }^{3} \mathrm{H}\right]$ thymidine incorporation assay}

Cells were seeded in T-25 culture flasks (Greiner, Nuertingen, Germany) and cultivated for $24 \mathrm{~h}$. Then, exponentially growing adherent cells were irradiated $(1 \times 10 \mathrm{~Gy})$, trypsinized, and counted. Appropriate cell numbers $\left(5 \times 10^{3}\right.$ cells/well) were resuspended in culture medium, plated into 96 well flat-bottom plates (150 $\mu \mathrm{l} /$ well), and incubated for another 24 and $48 \mathrm{~h}$ in the presence of $1 \mu \mathrm{Ci}\left[{ }^{3} \mathrm{H}\right.$ ]thymidine. Irrespective of the pretreatment, $12 \mathrm{~h}$ after seeding, all tumor cells became adherent, as determined by phase-contrast light microscopic inspection (data not shown). $\left[{ }^{3} \mathrm{H}\right]$ thymidine uptake was measured in a scintillation counter (Perkin Elmer Life Sciences, Boston, MA, USA).

\section{Cell cycle analysis}

DNA content was analyzed in ethanol (80\%)-fixed untreated and irradiated $(1 \times 10$ Gy) carcinoma cells. Following a washing step in $1 \mathrm{mM}$ EDTA/
PBS and resuspension in PBS $(1 \mathrm{ml}), 10 \mu l$ propidium iodide solution $(5 \mathrm{mg} / \mathrm{ml})$ and $10 \mu \mathrm{l}$ ribonuclease $(10 \mu \mathrm{g} / \mathrm{ml})$ were added. Cells were analyzed by flow cytometry (FACSCalibur, Becton Dickinson, Heidelberg, Germany) after an incubation period of $20 \mathrm{~min}$ at room temperature.

\section{Cell-mediated lympholysis assay (CML) and antibody blocking assays}

NK cells were generated from heparinized peripheral blood $(200 \mathrm{ml})$ of healthy human individuals, following Ficoll density gradient centrifugation and CD94 antibody-based magnetic bead cell sorting, according to the CD56 antibody standard protocol (MidiMACS; Miltenyi, Bergisch Gladbach, Germany). After a 4-day stimulation period with low-dose IL-2 (100 IU/ml; Chiron) plus $2 \mu \mathrm{g} / \mathrm{ml}$ Hsp70 peptide TKD (aa ${ }_{450-463}$; TKDNNLLGRFELSG), the cytolytic response was tested against Hsp70 high-expressing $\mathrm{CX}+$, Colo + , and HeLa Bag-4 and low-expressing CX-, Colo-, and HeLa neo cells, either untreated or following irradiation $(1 \times 10 \mathrm{~Gy})$ and a recovery period of $24 \mathrm{~h}$, in a standard $\left[{ }^{51} \mathrm{Cr}\right]$ assay. ${ }^{54}$ Briefly, different dilutions of effector and target cells (40:1 to $2: 1)$ were coincubated in duplicates for $4 \mathrm{~h}$ at $37^{\circ} \mathrm{C}$, in a final volume of $200 \mu \mathrm{l}$. Then, supernatants $(30 \mu \mathrm{l})$ were collected and radioactivity was measured on a $\gamma$-counter (Topcount, Packard instrument). Antibody blocking studies were performed either with Hsp70 (cmHsp70.1), Bag-4 (H-300; IMG-152), Hsp40 (SPA-400, SPA-460), Hsp60 (SPA-806), or Hsp90 (SPA-830) antibodies. Briefly, after radioactive labeling, target cells $\left(0.3 \times 10^{6}\right)$ were incubated with the relevant antibodies $(10 \mu \mathrm{g} / \mathrm{ml})$ for $15 \mathrm{~min}$.

The percentage specific lysis was determined according to the following equation: \% lysis = experimental release-spontaneous release)/(maximum release - spontaneous release $) \times 100$. Percentage spontaneous release of each target cell was less than $25 \%$.

\section{Miscellaneous}

Chemicals were from Sigma (Munich, Germany), Merck (Darmstadt, Germany), or Roth (Karlsruhe, Germany), if not indicated otherwise.

\section{Statistics}

For statistical analysis, Student's t-test was used. A confidence level above $95 \%(P<0.05)$ was determined as significant.

\section{Acknowledgements}

We thank Lydia Rossbacher and Gerald Thonigs for the excellent technical assistance. This work was supported by a BioChance Grant 0312338 of the Bundesministerium für Forschung und Technologie (BMBF), by the EU-project TRANSEUROPE (QLRT 2001 01936), and by multimmune $\mathrm{GmbH}$.

\section{References}

1. Hartl FU and Hayer-Hartl M (2002) Molecular chaperones in the cytosol: from nascent chain to folded protein. Science 295: 1852-1858

2. Pilon M and Schekman R (1999) Protein translocation: how Hsp70 pulls it off. Cell 97: 679-682

3. Frydman J and Hohfeld J (1997) Chaperones get in touch: the Hip-Hop connection. Trends Biochem. Sci. 22: 87-92 
4. Jaattela M (1999) Escaping cell death: survival proteins in cancer. Exp. Cell Res. 248: 30-43

5. Takayama S, Xie Z and Reed JC (1999) An evolutionarily conserved family of $\mathrm{Hsp} 70 / \mathrm{Hsc70}$ molecular chaperone regulators. J. Biol. Chem. 274: 781-786

6. Takayama S and Reed JC (2001) Molecular chaperone targeting and regulation by BAG family proteins. Nat. Cell Biol. 3: 237-241

7. Doong $\mathrm{H}$, Vrailas A and Kohn EC (2002) What's in the 'BAG'? - a functional domain analysis of the BAG-family proteins. Cancer Lett. 188: 25-32

8. Tschopp J, Martinon F and Hofmann K (1999) Apoptosis: silencing the death receptors. Curr. Biol. 9: 381-384

9. Miki K and Eddy EM (2002) Tumor necrosis factor receptor 1 is an ATPase regulated by silencer of death domain. Mol. Cell. Biol. 22: 2536-2543

10. Van Molle W, Wielockx B, Mahieu T, Takada M, Taniguchi T, Sekikawa K and Libert C (2002) HSP70 protects against TNF-inducedd lethal inflammatory shock. Immunity 16: 685-695

11. Antoku K, Maser RS, Scully WJ, Delach SM and Johnson DE (2001) Isolation of Bc1-2 binding proteins that exhibit homology with BAG-1 and suppressor of death domain protein. Biochem. Biophys. Res. Commun. 286: 1003-1010

12. Song J, Takeda M and Morimoto RI (2001) Bag1-Hsp70 mediates a physiological stress signaling pathway that regulates Raf-1/ERK and cell growth. Nat. Cell Biol. 3: 276-282

13. Briknarova K, Takayama S, Brive L, Havert ML, Knee DA, Velasco J, Homma S, Cabezas E, Stuart J, Hoyt DW, Satterhwait AC, Llinas M, Reed JC and Ely KR (2001) Structural analysis of BAG1 cochaperone and its interactions with Hsc70 heat shock protein. Nat. Struct. Biol. 8: 349-352

14. Bardelli A, Longati $P$, Alberto D, Goruppi S, Schneider $C$, Ponzetto $C$ and Comoglio PM (1996) HGF receptor associates with the anti-apoptotic protein BAG-1 and prevents cell death. EMBO J. 15: 6205-6212

15. Sondermann H, Scheufler C, Schneider C, Hohfeld J, Hartl FU and Moarefi I (2001) Structure of a Bag/Hsc70 complex: convergent functional evolution of Hsp70 nucleotide exchange factors. Science 291: 1553-1557

16. Ferrarini M, Heltai S, Zocchi MR and Rugarli C (1992) Unusual expression and localization of heat-shock proteins in human tumor cells. Int. J. Cancer 51: 613-619

17. Multhoff $G$, Botzler $C$, Wiesnet M, Muller E, Meier T, Wilmanns $W$ and Issels RD (1995) A stress-inducible 72-kDa heat-shock protein (HSP72) is expressed on the surface of human tumor cells, but not on normal cells. Int. J. Cancer 61: 272-279

18. Shin BK, Wang H, Yim AM, Le Naour F, Brichory F, Jang JH, Zhao R, Puravs E, Tra J, Michael CW, Misek DE and Hanash SM (2003) Global profiling of the cell surface proteome of cancer cells uncovers an abundance of proteins with chaperone function. J Biol. Chem. 278: 7607-7616

19. Botzler C, Ellwart J, Gunther W, Eissner G and Multhoff G (1999) Synergistic effects of heat and ET-18-OCH3 on membrane expression of hsp70 and lysis of leukemic K562 cells. Exp. Hematol. 27: 470-478

20. Gehrmann M, Pfister K, Hutzler P, Gastpar R, Margulis B and Multhoff G (2002) Effects of anti-neoplastic agents on cytosolic and membrane-bound heat shock protein 70 (Hsp70) levels. Biol. Chem. 383: 1715-1725

21. Suzuki K and Watanabe M (1992) Augmented expression of HSP72 protein in normal human fibroblasts irradiated with ultraviolet light. Biochem. Biophys. Res. Commun. 186: 1257-1264

22. Sierra-Rivera E, Voorhees GJ and Freeman ML (1993) Gamma irradiation increases hsp70 in Chinese hamster ovary cells. Radiat. Res. 135: 40-45

23. Matsumoto $\mathrm{H}$, Wang $\mathrm{X}$ and Ohnishi $\mathrm{T}$ (1995) Binding between wild-type p53 and hsp72 accumulated after UV and gamma-ray irradiation. Cancer Lett. 92: 127-133

24. Hennequin $C$ and Favaudon V (2002) Biological basis for chemo-radiotherapy interactions. Eur. J. Cancer 38: 223-230

25. Bartelink H, Schellens JH and Verheji M (2002) The combined use of radiotherapy and chemotherapy in the treatment of solid tumours. Eur. J. Cancer 38: 216-222

26. Travis LB (2002) Therapy-associated solid tumors. Acta Oncol. 41: 323-333

27. Shinomiya $N(2001)$ New concepts in radiation-induced apoptosis: 'premitotic apoptosis' and 'postmitotic apoptosis'. J. Cell Mol. Med. 5: 240-253

28. Ozawa F, Friess H, Zimmermann A, Kleeff J and Buchler MW (2000) Enhanced expression of Silencer of death domains (SODD/BAG-4) in pancreatic cancer. Biochem. Biophys. Res. Commun. 271: 409-413
29. Multhoff G, Botzler C, Jennen L, Schmidt J, Ellwart J and Issels R (1997) Heat shock protein 72 on tumor cells: a recognition structure for natural killer cells. J. Immunol 158: 4341-4350

30. Multhoff G, Mizzen L, Winchester CC, Milner CM, Wenk S, Eissner G, Kampinga HH, Laumbacher B and Johnson J (1999) Heat shock protein 70 (Hsp70) stimulates proliferation and cytolytic activity of natural killer cells. Exp. Hematol. 27: 1627-1636

31. Multhoff G, Pfister K, Gehrmann M, Hantschel M, Gross C, Hafner M and Hiddemann W (2001) A 14-mer Hsp70 peptide stimulates natural killer (NK) cell activity. Cell Stress Chaperones 6: 337-344

32. Jaattela M, Wissing D, Kokholm K, Kallunki T and Egeblad M (1998) Hsp70 exerts its anti-apoptotic function downstream of caspase-3-like proteases. EMBO J. 17: 6124-6134

33. Takayama S, Bimston DN, Matsuzawa S, Freeman BC, Aime-Sempe C, Xie Z, Morimoto RI and Reed JC (1997) BAG-1 modulates the chaperone activity of Hsp70/Hsc70. EMBO J. 16: 4887-4896

34. Takayama S, Sato T, Krajewski S, Kochel K, Irie S, Millan JA and Reed JC (1995) Cloning and functional analysis of BAG-1: a novel Bcl-2-binding protein with anti-cell death activity. Cell 80: 279-284

35. Liu R, Takayama S, Zheng Y, Froesch B, Chen GQ, Zhang X, Reed JC and Zhang XK (1998) Interaction of BAG-1 with retinoic acid receptor and its inhibition of retinoic acid-induced apoptosis in cancer cells. J. Biol. Chem. 273: 16985-16992

36. Kanelakis KC, Morishima Y, Dittmar KD, Galigniana MD, Takayama S, Reed JC and Pratt WB (1999) Differential effects of the hsp70-binding protein BAG-1 on glucocorticoid receptor folding by the hsp90-based chaperone machinery. J. Biol. Chem. 274: 34134-34140

37. Song J, Takeda M and Morimoto RI (2001) Bag1-Hsp70 mediates a physiological stress signalling pathway that regulates Raf-1/ERK and cell growth. Nat. Cell Biol. 3: 276-282

38. Doong H, Price J, Kim YS, Gasbarre C, Probst J, Liotta LA, Blanchette J, Rizzo $\mathrm{K}$ and Kohn E (2000) CAIR-1/BAG-3 forms an EGF-regulated ternary complex with phospholipase C-gamma and Hsp70/Hsc70. Oncogene 19: 4385-4395

39. Liao Q, Ozawa F, Friess H, Zimmermann A, Takayama S, Reed JC, Kleeff J and Buchler MW (2001) The anti-apoptotic protein BAG-3 is overexpressed in pancreatic cancer and induced by heat stress in pancreatic cancer cell lines. FEBS Lett. 503: 151-157

40. Thress K, Henzel W, Shillinglaw W and Kornbluth S (1998) Scythe: a novel reaper-binding apoptotic regulator. EMBO J. 17: 6135-6143

41. Botzler C, Li G, Issels RD and Multhoff G (1998) Definition of extracellular localized epitopes of Hsp70 involved in an NK immune response. Cell Stress Chaperones 3: 6-11

42. Jiang Y, Woronicz JD, Liu W and Goeddel DV (1999) Prevention of constitutive TNF receptor 1 signaling by silencer of death domains. Science 283: 543-546

43. Wei YQ, Zhao X, Kariya $Y$, Teshigawara $K$ and Uchida A (1995) Inhibition of proliferation and induction of apoptosis by abrogation of heat-shock protein (HSP) 70 expression in tumor cells. Cancer Immunol. Immunother. 40: 73-78

44. Gross C, Koelch W, DeMaio A, Arispe N and Multhoff G (2003) Cell surfacebound heat shock protein 70 (Hsp70) mediates perforin-independent apoptosis by specific binding and uptake of granzyme B. J. Biol. Chem. 278: 4117341181

45. Becker T, Hartl FU and Wieland F (2002) CD40, an extracellular receptor for binding and uptake of Hsp70-peptide complexes. J. Cell Biol. 158: 1277-1285

46. Asea A, Kraeft SK, Kurt-Jones EA, Stevenson MA, Chen LB, Finberg RW, Koo GC and Calderwood SK (2000) HSP70 stimulates cytokine production through a CD14-dependant pathway, demonstrating its dual role as a chaperone and cytokine. Nat. Med. 6: 435-442

47. Binder RJ, Han DK and Srivastava PK (2000) CD91: a receptor for heat shock protein gp96. Nat. Immunol. 1: 151-155

48. Gross C, Hansch D, Gastpar R and Multhoff G (2003) Interaction of heat shock protein 70 peptide with NK cells involves the NK receptor CD94. Biol. Chem. 384: $267-279$

49. Kleinjung T, Arndt O, Feldmann HJ, Bockmuhl U, Gehrmann M, Zilch T, Pfister $\mathrm{K}$, Schoenberger J, Marienhagen J, Eilles $\mathrm{C}$, Rossbacher $\mathrm{L}$ and Multhoff $\mathrm{G}$ (2003) Heat shock protein 70 (Hsp70) membrane expression on head-andneck cancer biopsy-a target for natural killer (NK) cells. Int. J. Radiat. Oncol. Biol. Phys. 57: 820-826 
50. Eichholtz-Wirth H, Fritz E and Wolz L (2003) Overexpression of the 'silencer of death domain', SODD/BAG-4, modulates both TNFR1- and CD95-dependent cell death pathways. Cancer Lett. 194: 81-89

51. Evans WH (1978) Preparation and Characterization of Mammalian Plasma Membranes, Work TS and Work E, eds New York: Elsevier

52. Laemmli UK (1970) Cleavage of structural proteins during the assembly of the head of bacteriophage T4. Nature 227: 680-685
53. Towbin H, Staehelin T and Gordon J (1979) Electrophoretic transfer of proteins from polyacrylamide gels to nitrocellulose sheets: procedure and some applications. Proc. Natl. Acad. Sci. USA 76: 4350-4354

54. MacDonald HR, Engers HD, Cerottini JC and Brunner KT (1974) Generation of cytotoxic T lymphocytes in vitro. II. Effect of repeated exposure to alloantigens on the cytotoxic activity of long-term mixed leukocyte cultures. J. Exp. Med. 140: $718-730$ 